\title{
Intrinsic Program for Migration of Cerebellar Granule Cells In Vitro
}

\author{
Elina Yacubova and Hitoshi Komuro \\ Department of Neurosciences, Lerner Research Institute, The Cleveland Clinic Foundation, Cleveland, Ohio 44195
}

Cerebellar granule cells exhibit distinct modes of migration in different cortical layers. The role of external cues in controlling these alterations has been suggested, but the significance of internal programs is not well understood. In the present study, we examined autonomous changes of migratory behavior of isolated granule cells in microexplant cultures of the postnatal mouse cerebellum. We found that isolated granule cells sequentially go through three characteristic phases of migration without cell-cell contact. In the first phase (0-20 hr in vitro) granule cells exhibit the highest rate of turning behavior and have multiple short processes. The length of the movement cycle is shortest. In the second phase (20-40 hr in vitro), granule cells extend a long and thick process and exhibit an elongated cycle of movement. Their speed is fastest, whereas the rate of turning is lowest. In the third phase (40-60 hr in vitro), granule cells slow down their movement and slightly increase their turnings. The length of the movement cycle further increases. At the end, the cells become permanently stationary, extend a lamellipodium around the soma, and emit several thin processes. Interestingly, granule cells sequentially develop four different modes of turning. These results indicate that internal (intrinsic) programs control alterations of granule cell behavior in a stage-dependent manner, suggesting that such programs independent of local cell-cell contacts may be essential for granule cell translocation in the developing cerebellum.

Key words: cerebellar development; granule cell; neuronal cell migration; confocal microscopy; microexplant culture and rate of cell movement; inherent behavior
During translocation from their birthplace to their final destinations, granule cells exhibit a distinct mode and tempo of migration in the different cortical layers of the early postnatal cerebellum (Rakic, 1971; Komuro and Rakic, 1995, 1998a; Komuro et al., 2001; Komuro and Yacubova, 2001; Yacubova and Komuro, 2002). This layer-specific alteration of migratory behavior is likely to be induced by responses to local environmental cues. In fact, recent studies demonstrate that contact with the surfaces of neighboring cells and multiple external guidance cues, including attractive and repulsive signals, play a crucial role in controlling granule cell migration (Hatten and Mason, 1990; Rakic et al., 1994; Hatten and Heintz, 1995; Soriano et al., 1997; Komuro and Rakic, 1998b; Lin and Cepko, 1998; Alcantara et al., 2000; Yacubova and Komuro, 2002). In particular, the role of cell adhesion and extracellular matrix molecules in granule cell migration has been well established (Edmondson and Hatten, 1987; Fishell and Hatten, 1991; Fishman and Hatten, 1993; Cameron and Rakic, 1994; Anton et al., 1996; Cameron et al., 1997).

Although external cues and cell-cell contact are essential for selection of migratory paths and termination of cell movement, alterations of migratory behavior of immature neurons may also depend, at least in part, on an internal clock or intrinsic programs (Morest, 1970; Trenkner and Sidman, 1977; Trenkner et al., 1984; Liesi, 1985; Liang and Crutcher, 1992, 1993). For example, in microexplant cultures granule cells exhibit sequential and stereotypical behaviors in isolation as follows: (1) granule cells migrate radially along bundles of their neurites, (2) the cells change their

Received Nov. 2, 2001; revised March 21, 2002; accepted April 16, 2002.

This work was supported by the Cleveland Clinic Foundation and Whitehall Foundation (H.K.). We thank Drs. Kenneth Wikler, Mark Perin, and Keiko Hirose for comments on this manuscript. We also thank Janeen Neffenger for technical help.

Correspondence should be addressed to Dr. Hitoshi Komuro, Department of Neurosciences/NC30, Lerner Research Institute, The Cleveland Clinic Foundation, 9500 Euclid Avenue, Cleveland, OH 44195. E-mail: komuroh@ccf.org.

Copyright (ㄷ) 2002 Society for Neuroscience $0270-6474 / 02 / 225966-16 \$ 15.00 / 0$ orientation perpendicular to their radial neurites, by protruding a short process from the cell body, and (3) their somata adhere to each other to form aggregates (Nakatsuji and Nagata, 1989; Nagata and Nakatsuji, 1990). Moreover, sequential changes in granule cell morphology in the absence of cell-cell contact are observed in low-density cultures (Powell et al., 1997). In these cultures, granule cells first extend a single neurite and then develop bipolar morphology with a second long neurite extending from the opposite pole of the soma. Thereafter, short neurites develop around the cell body. These observations suggest that intrinsic programs may be involved in sequential changes in migratory behavior and morphology of granule cells.

In this study, we examined autonomous changes in granule cell migration in vitro. The real time observations of cell movement reveal when and how isolated granule cells initiate, alter, and complete their migration without cell-cell interaction and external stop signals. The present results indicate that granule cells intrinsically and sequentially alter the rate, turning, and mode of migration and their morphology in an age-dependent manner, suggesting that intrinsic programs may play a crucial role in execution of granule cell migration in the developing cerebellum.

\section{MATERIALS AND METHODS}

Microexplant culture of early postnatal cerebella. All procedures were in strict accordance with the National Institutes of Health Guide for the Care and Use of Laboratory Animals and were approved by the Institutional Animal Care and Use Committee of the Cleveland Clinic Foundation. Cerebella obtained from postnatal day 0 (P0)-P2 mice (CD-1) were quickly removed from the skull, placed in cold HBSS and freed from meninges and choroid plexus. Cerebellar slices were then made with a surgical blade, from which white matter and deep cerebellar nuclei were removed. Rectangular pieces $(50-100 \mu \mathrm{m})$ were dissected out from the remaining tissue, which mainly consisted of the cerebellar gray matter, using a surgical blade under a dissecting microscope. Such prepared microexplants were rinsed with the culture medium and placed on the poly-L-lysine-laminin-coated glass coverslips (one microexplant per coverslip) with $50 \mu \mathrm{l}$ of the culture medium. We used poly-L-lysine and 
laminin as substrata, because these materials provide scaffold for migrating granule cells and promote their movement (Nagata and Nakatsuji, 1990; Liang and Crutcher 1992). Coating with poly-L-lysine was made on glass coverslips (25 mm in diameter; Macalaster Bicknell Corp.). Sterile coverslips, immersed in a $100 \mu \mathrm{g} / \mathrm{ml}$ poly-L-lysine hydrobromide (molecular weight, >300,000; Sigma, St. Louis, MO) solution were dried under a sterile air flow, rinsed with distilled water, and used as the poly-L-lysine substratum. Approximately $100 \mu \mathrm{l}$ of a solution of laminin $(20 \mu \mathrm{g} / \mathrm{ml}$; Sigma) was applied to the dried poly-L-lysine substratum for $2 \mathrm{hr}$ at $37^{\circ} \mathrm{C}$, rinsed three times with culture medium, and used immediately as the poly-L-lysine-laminin substrate. We chose laminin from among extracellular matrix molecules, because laminin promotes migration of immature neurons (Liesi, 1990, 1992), and we were aware that the rate of neuronal cell movement depends on the concentrations of laminin-coated on coverslips (Liang and Crutcher, 1993). Higher $(50-100 \mu \mathrm{g} / \mathrm{ml})$ or lower (1-5 $\mu \mathrm{g} / \mathrm{ml})$ concentrations of laminin significantly reduced the rate of granule cell movement. Therefore, we used a concentration of $20 \mu \mathrm{g} / \mathrm{ml}$ of laminin that allows granule cells to migrate at the fastest rate. One hour after plating, each coverslip was transferred into a Petri dish (35 $\mathrm{mm}$ in diameter; Corning, Corning, NY), added with $1 \mathrm{ml}$ of the culture medium, and put in a $\mathrm{CO}_{2}$ incubator $\left(37^{\circ} \mathrm{C}, 95 \%\right.$ air, $\left.5 \% \mathrm{CO}_{2}\right)$. The incubation medium consisted of minimum essential medium (Invitrogen, San Diego, CA) supplemented with $10 \%$ fetal calf serum, $30 \mathrm{~mm}$ glucose, $1.8 \mathrm{~mm}$ glutamine, $24 \mathrm{~mm} \mathrm{NaHCO}_{3}, 90 \mathrm{U} / \mathrm{ml}$ penicillin, and $90 \mu \mathrm{g} / \mathrm{ml}$ streptomycin.

In some experiments, to determine whether autonomous changes in migratory behavior of granule cells depend on adhesive substrates, we used a fibronectin $(20 \mu \mathrm{g} / \mathrm{ml}$; Sigma) as a substitute for laminin. In addition, we prepared microexplant cultures from postnatal 5-d-old mouse (CD-1) cerebella to examine whether granule cells isolated from different postnatal stages undergo the same patterns of changes in migratory behavior in vitro. Furthermore, to determine whether granule cells cultured on different concentration of laminin display the same sequential changes in migratory behavior, we used a lower $(4 \mu \mathrm{g} / \mathrm{ml})$ and higher $(100 \mu \mathrm{g} / \mathrm{ml})$ concentration of laminin.

Methods for real time observation of granule cell migration in microexplant cultures. After 3-70 hr in vitro, coverslips were transferred into the chamber of a microincubator (PDMI-2; Medical System Corp.) attached to the stage of an inverted microscope (DM IRBE; Leica, Nussloch, Germany). The rate of cell movement is closely related to the temperature of the medium; lowering the medium temperature slows cell movement (Rakic and Komuro, 1995). Therefore, the chamber temperature was kept at $37.0 \pm 0.5^{\circ} \mathrm{C}$ using a temperature controller (TC-202; Medical System Corp.), and the cells were provided with constant gas flow $\left(95 \% \mathrm{O}_{2}, 5 \% \mathrm{CO}_{2}\right)$. A laser-scanning confocal microscope (TCS SP; Leica) was used to visualize migrating granule cells in the microexplant cultures (Komuro and Rakic, 1996, 1999; Yacubova and Komuro, 2002). The granule cells were illuminated with a $488 \mathrm{~nm}$ wavelength light from an argon laser through an inverted microscope equipped with a $63 \times$ oil-immersion objective (numerical aperture, 1.32; Leica), and light transmitted through granule cells was detected by photomultiplier. To clearly resolve movement of migrating cells, image data typically were collected at an additional zoom factor of 1.2-2. Time lapse imaging of live cells can produce phototoxic effects in the imaged cells. Indeed, when cells were imaged with very high incident illumination intensity, or imaged too frequently, we invariably saw changes in the structure or dynamics of the migrating granule cells. However, when the incident illumination was sufficiently attenuated, the cells could be imaged for many hours without signs of photodynamic damage. To protect the migrating granule cells from any cytotoxic effect of the laser beam, the light level was reduced by $99 \%$. Images of the granule cells in a single focal plane were collected with laser scans every 10-60 sec for up to 20 $\mathrm{hr}$ and recorded on an external drive (Jaz 2GB; Iomega). The distance traveled by a migrating granule cell was defined as the absolute value of the change in its position during the entire time lapse session. Statistical significance between experimental groups was tested by Student's $t$ test.

\section{RESULTS}

To examine intrinsic changes of migratory behavior of granule cells, we used microexplant cultures of the P0-P2-d-old mouse (CD-1) cerebellum. In these cultures, $>95 \%$ of migrating neurons were granule cells, which were easily distinguished from other neurons by the small size of their cell bodies (Nagata and Nakatsuji, 1990; Komuro and Rakic, 1996). Although granule cells were prepared from the external granular layer (EGL) and the internal granular layer (IGL) of all lobules of the cerebellum, the vast majority of granule cells were derived from the EGL, because at age of $\mathrm{P} 0-\mathrm{P} 2$ the IGL only contains very small numbers of postmigratory granule cells, and the peak of granule cell migration occurs between P8 and P10 (Miale and Sidman, 1961; Fujita et al., 1966; Altman, 1972). Therefore, the majority of granule cells were at the same developmental stage (or the same age). In these cultures, granule cells migrated on the poly-L-lysinelaminin-coated glass coverslip for up to $\sim 60 \mathrm{hr}$ in vitro with or without contacting other neurons, neuronal processes, and glial cells. To determine features of intrinsic migratory behavior, we chose granule cells that did not have any contact with other cells during a period of migration, because such interaction could affect the inherent migratory behavior. To this end, we selected granule cells that located farthest from the microexplant of cerebellum. Furthermore, those selected granule cells were at least $100 \mu \mathrm{m}$ away from other granule cells, neuronal processes, and glial cells at a period of $0-10 \mathrm{hr}$ in vitro, $200 \mu \mathrm{m}$ away at a period of 10-30 hr in vitro, and $300 \mu \mathrm{m}$ away at a period of 30-60 hr in vitro. This selection allowed us to determine the migratory behavior of granule cells that had not experienced any cell contact or had least contact during an entire period of their in vitro migration. If granule cells contacted other cells or processes during a period of observation, the data obtained from these cells were excluded.

We analyzed a total of 145 granule cells and found that the majority of granule cells exhibited dynamic changes in their migratory behavior and morphology during a period of observation. Interestingly, such alterations depended on elapsed time after an initiation of cultures. In these cultures granule cells sequentially went through three characteristic phases of behavior and morphology. The first phase (PI) was a period of $0-20 \mathrm{hr}$ in vitro, when granule cells initiated their migration. The second phase II (PII) was a period of $20-40 \mathrm{hr}$ in vitro, when granule cells had their long leading processes and moved at the fastest rate. The third phase III (PIII) was a period of 40-60 hr in vitro, when granule cells terminated their migration. In the following sections, we presented typical examples showing sequential alterations of intrinsic migratory behavior and morphology of cerebellar granule cells as the differentiation of the cells goes on.

\section{Initial mode of intrinsic migratory behavior during the early stage of the first phase}

First, we determined how granule cells initiate their migration in the microexplant cultures. At $5 \mathrm{hr}$ in vitro a granule cell with its spherical cell body migrated out from the explant, repeatedly changed the shape of its soma from spherical to spindle and vice versa, and frequently turned to the left or right (Fig. 1 $A$ ). Interestingly, the cell exhibited a characteristic mode of turning behavior. For example, at the point at which the granule cell changed its direction of movement, it stopped its movement, became round, and then extended its cell body in the direction of the upcoming movement (shown in a period of 8-9 hr in vitro and a period of 11-2 hr in vitro in Fig. $1 B$ ). Shortly after the extension, the cell resumed its movement parallel to the direction of the longitudinal axis of the cell body. Although granule cell repeatedly extended small protrusions (Fig. $1 \mathrm{~A}$, arrows) from its soma, the cell did not follow the orientation of these short protrusions. The rate of cell movement had a sinusoidal pattern and gradually increased from $4-6 \mu \mathrm{m} / \mathrm{hr}$ during the first $3 \mathrm{hr}$ after recording to 10-35 $\mu \mathrm{m} / \mathrm{hr}$ (Fig. $1 C$ ). The overall rate of cell movement was 


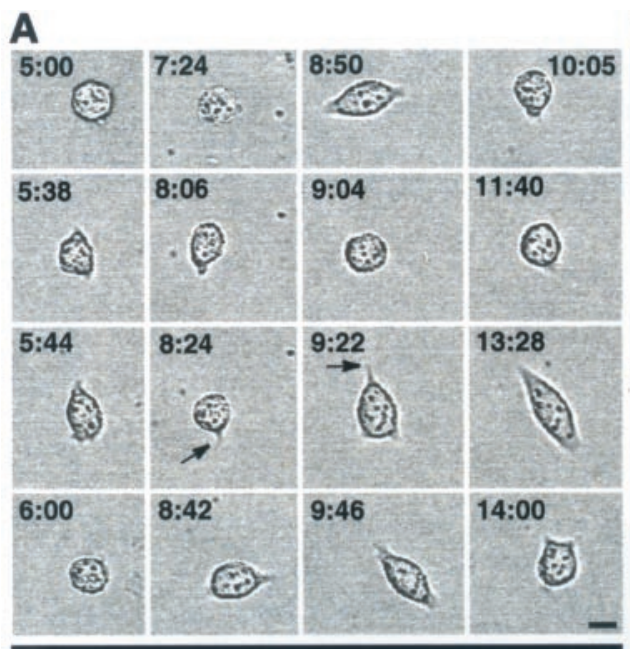

B
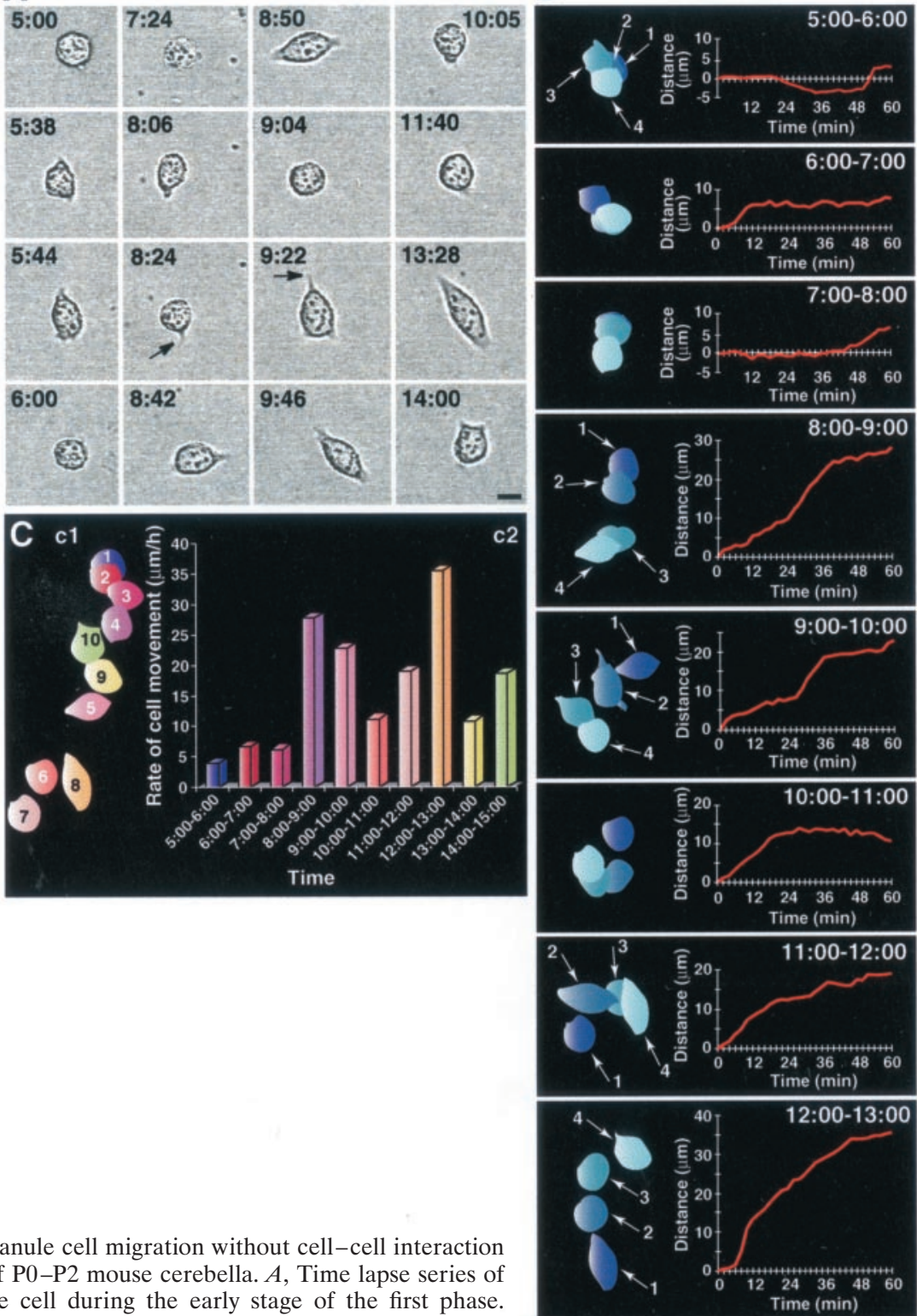

in the microexplant cultures of P0-P2 mouse cerebella. $A$, Time lapse series of images of a migrating granule cell during the early stage of the first phase. Elapsed time in vitro is indicated on top of each photograph. At $5 \mathrm{hr}$ in vitro, a granule cell repeatedly changed its soma shape and frequently turned right or left. Arrows indicate small protrusions extended from the soma. Scale bar, $5 \mu \mathrm{m}$. $B$, Changes in direction and rate of cell movement. Four images of the granule cell taken every $20 \mathrm{~min}$ (shown in $A$ ) are superimposed. The numbers $(1-4)$ represent the images taken at $0,20,40$, and 60 min during each 60 min recording, respectively. Elapsed time in vitro is indicated on top of each image. Each graph represents the total distance traveled by the granule cell as a function of elapsed time. $C$, Fluctuations of the rate of granule cell movement. $c 1$, Pseudocolor images represent images of the granule cell taken every $60 \mathrm{~min}$ shown in $A$. Each number represents the order of image taken. $c 2$, Graph showing the changes in average rate of cell movement. The color of each column corresponds to the
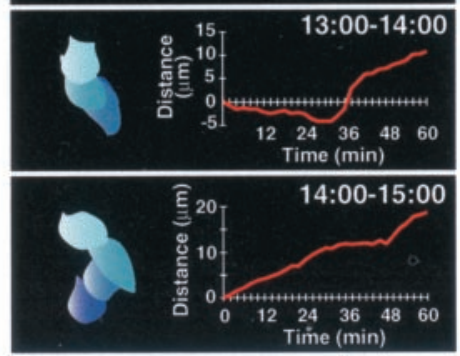
pseudocolor of each image in $c 1$.

$16.3 \mu \mathrm{m} / \mathrm{hr}$. As originally described by Nagata and Nakatsuji (1990), approximately one-third of the cells that migrated out from the explants of $\mathrm{P} 0-\mathrm{P} 2$ mouse cerebella within a few hours in vitro were labeled with 5-bromo-2'-deoxyuridine (BrdU), suggesting that some cells observed at the early stage of PI may be granule cell precursors (our unpublished results). These results indicate that at the earliest phase of migration granule cells and granule cell precursors exhibit frequent changes in direction of cell movement without extending a leading process.

\section{Formation of a leading process during the middle stage of the first phase}

We examined how granule cells start to extend their leading processes, which are hallmarks of migrating neurons. Figure 2 represents a typical example showing the development of a leading process. At $10 \mathrm{hr}$ in vitro, a granule cell had a round soma emitting very short, thin processes and was stationary (Fig. $2 A, B$ ). During periods between 10.5 and $11 \mathrm{hr}$ in vitro, the granule cell 
A
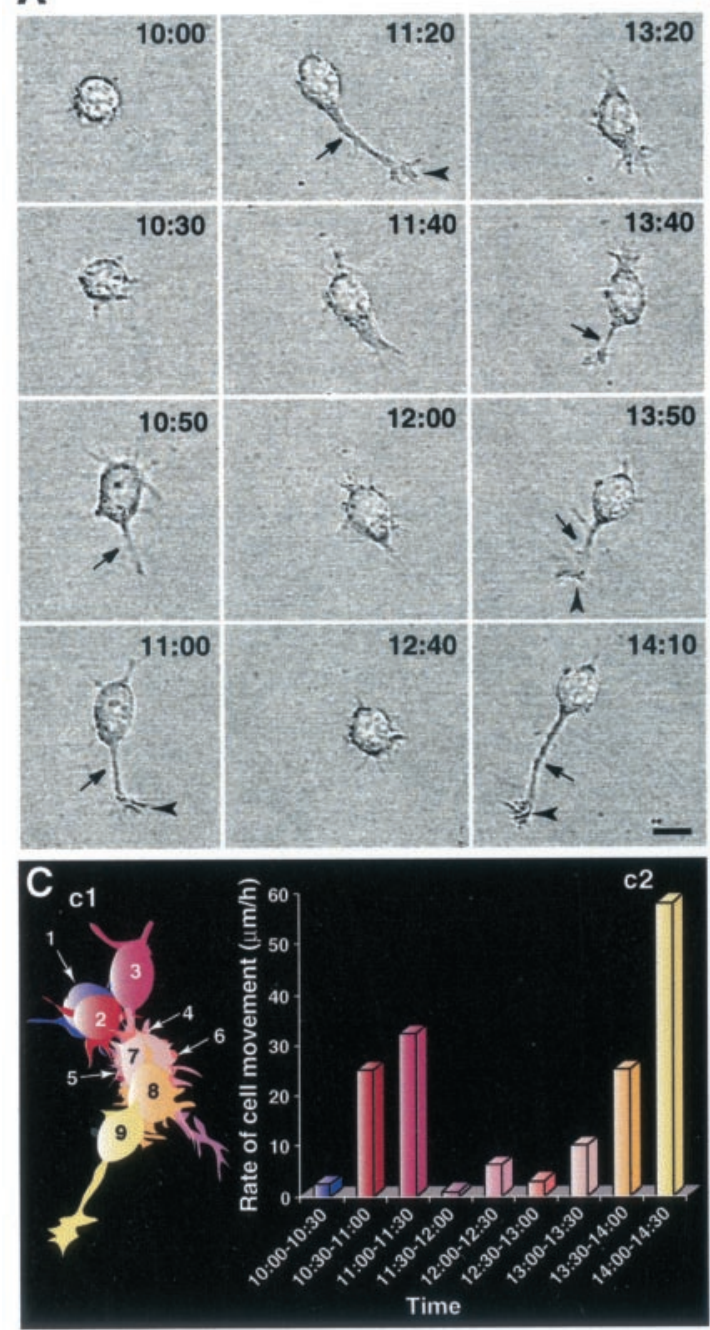

B
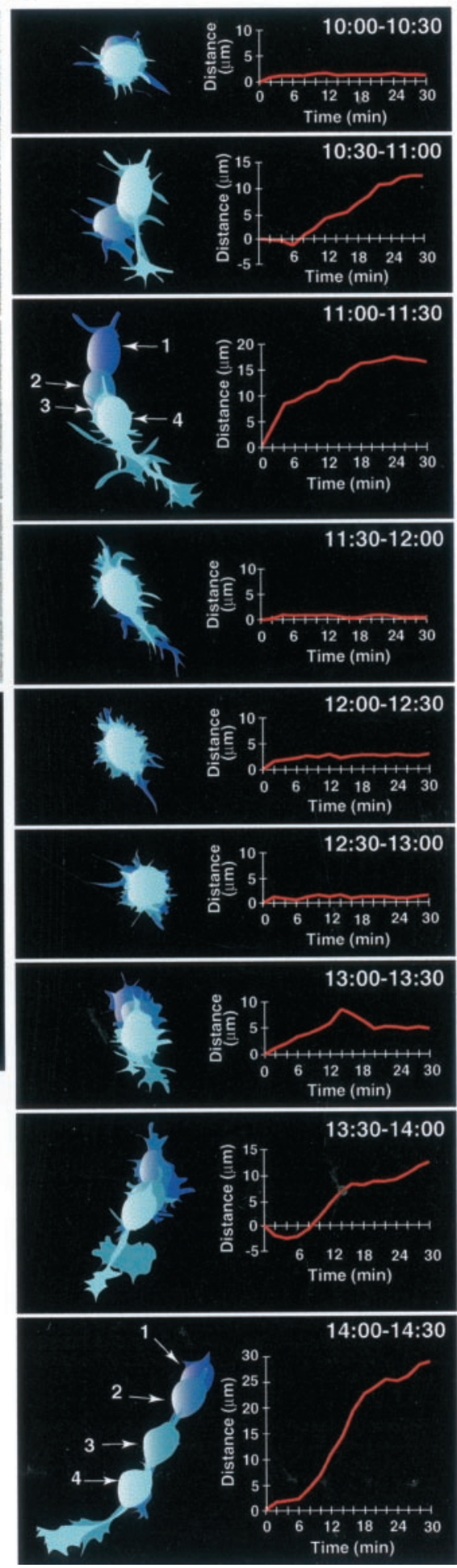

Figure 2. Migration of a granule cell during a period of the initial formation of leading processes. $A$, Time lapse series of images of a migrating granule cell during the middle stage of the first phase. Elapsed time in vitro is indicated on top of each photograph. At $10 \mathrm{hr}$ in vitro, a granule cell had a round soma emitting very short thin processes and was stationary. Thereafter, the granule cell gradually extended a thick leading process and then started to migrate in the direction of process extension. Arrows indicate short leading processes, and arrowheads indicate motile lamellipodia and filopodia at its tip. Scale bar, $7 \mu \mathrm{m}$. $B$, Changes in direction and rate of cell movement. Four images of the granule cell taken every $10 \mathrm{~min}$ (shown in $A$ ) are superimposed. The numbers (1-4) represent the images taken at $0,10,20$, and 30 min during each $30 \mathrm{~min}$ recording, respectively. Elapsed time in vitro is indicated on top of each image. Each graph represents the total distance traveled by the granule cell as a function of elapsed time. $C$, Fluctuations of the rate of granule cell movement. $c 1$, Pseudocolor images represent images of the granule cell taken every $30 \mathrm{~min}$ shown in $A$. Each number represents the order of image taken. $c 2$, Graph showing the changes in average rate of cell movement. The color of each column corresponds to the pseudocolor of each image in $c 1$.

gradually extended a thick leading process-like process (maximum length, $26 \mu \mathrm{m}$ ) with a motile lamellipodium and filopodia (arrowheads) at a tip, and the cell body became spindle shape (Fig. 2A). Interestingly, first, its soma slowly moved in an opposite direction of the process extension (Fig. 2B). However, after completion of the leading process extension, the soma reversed the direction of movement and moved in the direction of the process extension at a significantly increased rate at a period of 11-11.5 hr in vitro. Thereafter, the granule cell stopped its movement, withdrew the leading process, and then repeatedly emitted several short thin processes from its soma. After a prolonged stationary period between 11.5 and $13 \mathrm{hr}$ in vitro, the granule cell started to extend a new leading process-like process toward the different direction and then resumed its movement in the direc- 
tion of the process extension (Fig. $2 B$ ). Overall rate of cell movement was $18.1 \mu \mathrm{m} / \mathrm{hr}$ with a range between 1 and $58 \mu \mathrm{m} / \mathrm{hr}$ (Fig. 2C). These results indicate that during a period of initial formation of the leading process, granule cells repeatedly extended and withdrew short leading processes and moved at a fast rate only after the process fully extended. Furthermore, the extension of a new leading process toward a different direction was an essential prerequisite for changing the direction of cell movement.

\section{Development of mode of turning during the late stage of the first phase}

To further determine the intrinsic migratory behavior of granule cells at the first phase, we examined development of the turning behavior and the cycle of cell movement. At $15 \mathrm{hr}$ in vitro, a granule cell had three processes; one process was thick and more like a leading process, the others were thin and similar to the trailing processes (Fig. 3A). Initially, the granule cell moved toward the left side in the direction of the thick process during a period between 15 and $16 \mathrm{hr}$ in vitro. Later, the cell gradually stopped its movement and started to withdraw the thick process (Fig. $3 B$ ). When the length of the thick process became half of the original length at $17 \mathrm{hr}$ in vitro, the tip of the process started to turn to the right at an angle of $140^{\circ}$ and then extended in a new direction (the right side). Subsequently, the cell body resumed its movement in the new direction of the process extension (Fig. $3 B$ ). At $19 \mathrm{hr}$ in vitro the granule cell returned near the initial position and again became stationary (Fig. 3C). The overall rate of cell movement was $25.5 \mu \mathrm{m} / \mathrm{hr}$ with a range between 2 and $44 \mu \mathrm{m} / \mathrm{hr}$. These results suggest that at the end of the first phase granule cells start to develop a new mode of turning behavior; first, the tip of the leading process turns in a new direction and then, the cell body follows the changes. Furthermore, granule cells exhibit a dynamic cycle of cell advancement and stationary phase every 3 $\mathrm{hr}$; active cell migration lasts for $\sim 2 \mathrm{hr}$, and a stationary period is $\sim 1 \mathrm{hr}$.

\section{Dynamic changes in mode, tempo, and direction of cell movement during the early stage of the second phase}

In the postnatal cerebellum, 20-30 hr after the initiation of migration, granule cells alter the direction of cell movement from tangential to radial near the EGL/the molecular layer (ML) border (Komuro et al., 2001; Komuro and Yacubova, 2001). The initial step of this alteration is the development of vertical processes, and then the nucleus and the surrounding cytoplasm move inside the vertical process (Rakic, 1971; Komuro et al., 2001). The mechanisms involved in this transition are not well understood, but intrinsic migratory behavior may play a role in this alteration. To address this possibility, we determined the intrinsic migratory behavior of these cells at 20-30 hr in vitro. At $25 \mathrm{hr}$ in vitro a granule cell had a spindle shape soma with a thick, $90-\mu \mathrm{m}$-long "leading process" and a thin and short "trailing process" (Fig. $4 A$ ). Initially, the granule cell soma quickly moved toward the tip of the leading process at a rate between 40 and $70 \mu \mathrm{m} / \mathrm{hr}$ during a period between 25 and $25.5 \mathrm{hr}$ in vitro (Fig. $4 A$ ). Interestingly, at $26 \mathrm{hr}$ in vitro, the tip of the leading process started to bifurcate at an angle of $90^{\circ}$, and the leading process became a T-shape (Fig. $4 A, B)$. The granule cell soma advanced to the junction of two branches at a reduced rate, reached the branching point, and then paused at 27 hr in vitro (Fig. 4B). During a period between 27 and $28 \mathrm{hr}$ in vitro, the branch on the right side continuously extended, whereas the other branch collapsed and retracted. Subsequently, the soma changed orientation and resumed its movement toward the right branch at $28.5 \mathrm{hr}$ in vitro. Later, the granule cell underwent another bifurcation of the tip of the leading process, and the change in direction of cell body movement followed the extension and collapse of the branches. Overall rate of cell movement was $24.0 \mu \mathrm{m} / \mathrm{hr}$ with a range between 3 and $70 \mu \mathrm{m} / \mathrm{hr}$ (Fig. $4 C$ ). These results demonstrate that at $20-30 \mathrm{hr}$ in vitro granule cells developed another mode of turning without cell-cell contact as follows: (1) the tip of leading process bifurcated, (2) both branches extended in the opposite direction, (3) one of the branches collapsed and retracted, and (4) the cell body followed the direction of extension of the remaining branch. Isolated granule cells exhibited this mode of turning behavior throughout the second phase. These changes in intrinsic behavior may play a role in the alteration of direction of granule cell movement observed in the EGL-ML border in vivo.

\section{Prolonged stationary state during the late stage of the second phase}

After entering the Purkinje cell layer (PCL) of the developing cerebellum (30-40 hr after the initiation of migration), granule cells slowed down their movement and became stationary for $\sim 2$ hr (Komuro and Rakic, 1998a,b; Komuro and Yacubova, 2001). During the stationary period, the soma became transiently round, and the leading processes considerably shortened (Komuro and Rakic, 1998a). The detachment from the surface of Bergmann glia in the PCL is likely to trigger these changes, but intrinsic programs for cell migration may be involved in such alterations. To test this hypothesis, we examined the granule cell behavior at $30-40$ hr in vitro. At 30 hr in vitro, a granule cell had a spindleshaped soma with a thick and long leading process-like process and actively migrated at a rate of $\sim 48 \mu \mathrm{m} / \mathrm{hr}$ (Fig. $5 A, B$ ). At 33 $\mathrm{hr}$ in vitro, the cell slowed down its movement, retracted the long "leading process," and became stationary (Fig. 5B). During this stationary period that lasted for $3 \mathrm{hr}$ between 34 and $37 \mathrm{hr}$ in vitro, the granule cell started to extend two "leading processes" from the opposite side of the soma (Fig. $5 A, B$ ). Initially, these two processes shared similar morphological features in size and motile lamellipodia and filopodia at their tips. However, once the granule cell resumed its movement in the direction of one process at $37 \mathrm{hr}$ in vitro, the other process became thinner and transformed to "a trailing process"(Fig. 5A, open arrowhead). The overall rate of cell movement was $23.9 \mu \mathrm{m} / \mathrm{hr}$ (Fig. $5 C$ ). Although a few granule cells slowed down their movement and became stationary during the early stage of the second phase, the majority of granule cells underwent prolonged stationary state during the late stage of the second phase. These results suggest that at the late stage of the second phase granule cells became stationary for 2-3 hr and retracted their processes without external cues, suggesting that the prolonged stationary state of granule cells in the PLC may be controlled, at least in part, by intrinsic signals.

\section{Initial sign of termination of intrinsic migration during the early stage of the third phase}

Granule cells complete their migration within the IGL of the postnatal cerebellum (Komuro and Rakic, 1998a; Komuro and Yacubova, 2001), suggesting that granule cells may stop their movement in response to putative external stop signals scattered within the IGL. To test if internal programs are also responsible for the completion of granule cell migration, we examined the 
A
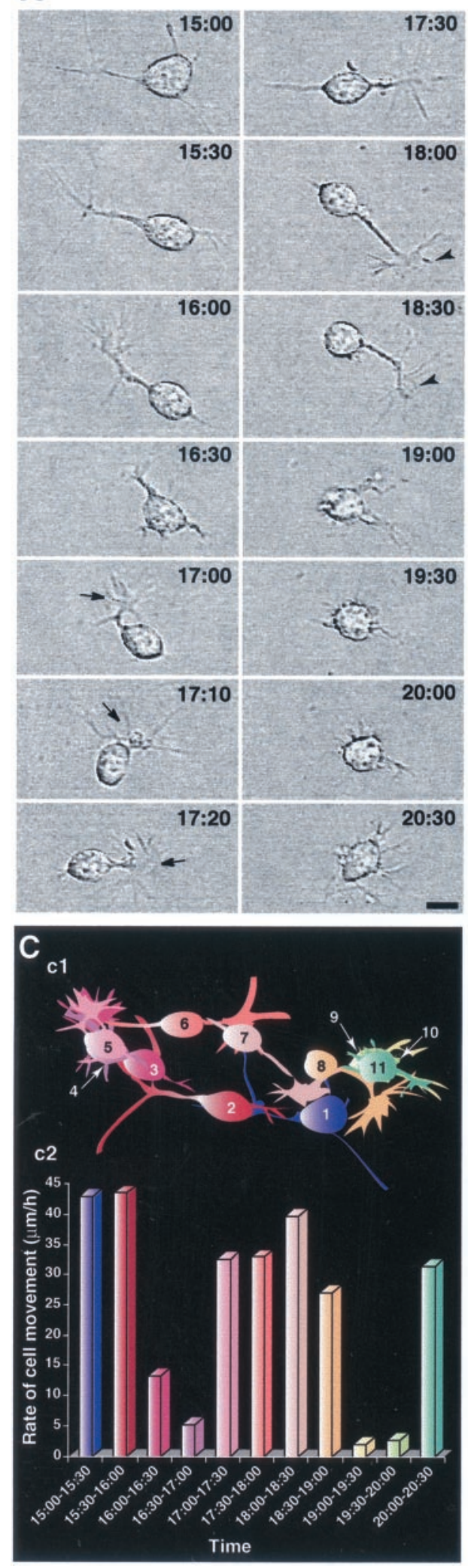

B
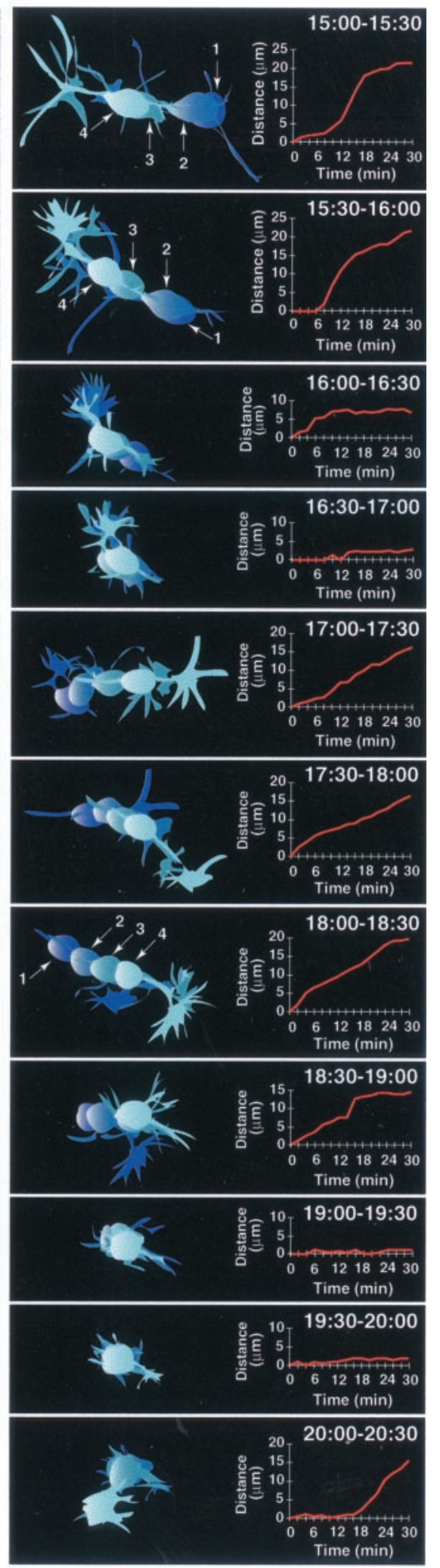

Figure 3. Development of new turning behavior and cycle of cell movement. $A$, Time lapse series of images of a migrating granule cell during the late stage of the first phase. Elapsed time in vitro is indicated on top of each photograph. At $15 \mathrm{hr}$ in vitro, a granule cell exhibited new mode of turning; first, the tip of leading process turned to new direction, and then the soma followed the changes. Arrows indicate sequential turnings of a short leading process. Arrowheads indicate motile lamellipodia and filopodia at a tip of the process. Scale bar, $7 \mu \mathrm{m}$. B, Changes in direction and rate of cell movement. Four images of the granule cell taken every $10 \mathrm{~min}$ (shown in $A$ ) are superimposed. The numbers (1-4) represent the images taken at 0,10 , 20, and 30 min during each 30 min recording, respectively. Elapsed time in vitro is indicated on top of each image. Each graph represents the total distance traveled by the granule cell as a function of elapsed time. $C$, Fluctuations of the rate of granule cell movement. $c 1$, Pseudocolor images represent images of the granule cell taken every 30 min shown in $A$. Each number represents the order of image taken. $c 2$, Graph showing the changes in average rate of cell movement. The color of each column corresponds to the pseudocolor of each image in $c 1$. final phase of granule cell migration in the microexplant cultures. At $40 \mathrm{hr}$ in vitro, a granule cell had a thick and long "leading process" with motile filopodia and lamellipodia at its tip (Fig. $6 A$ ). During a period of $40-43.5 \mathrm{hr}$ in vitro, the granule cell exhibited active cell movement at a rate ranging between 30 and $49 \mu \mathrm{m} / \mathrm{hr}$ and altered the direction of cell body movement with a similar mode observed in PII (shown in Fig. 4). Interestingly, at $44 \mathrm{hr}$ in vitro, the tip of leading process started to split into 
A
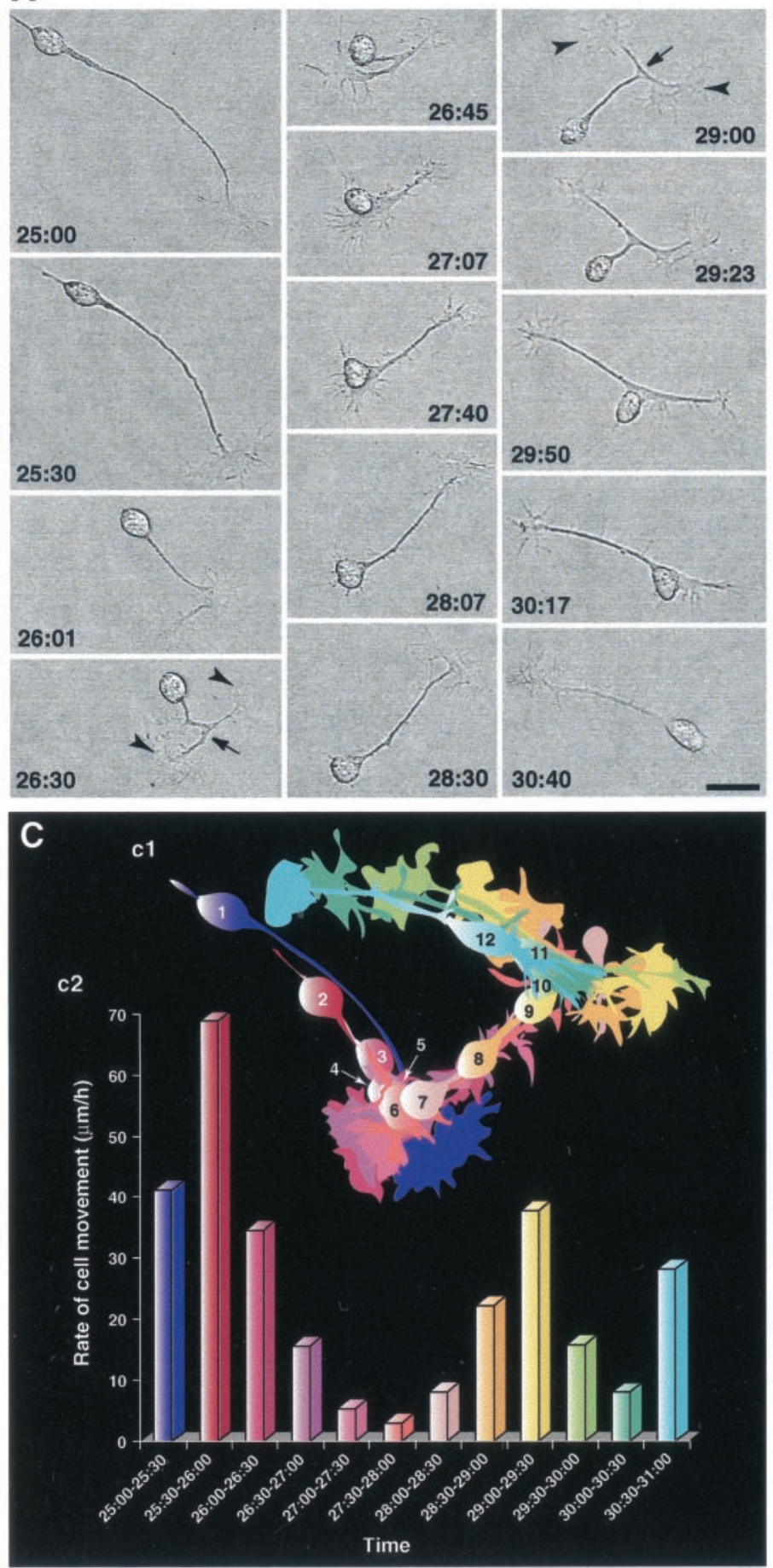

B
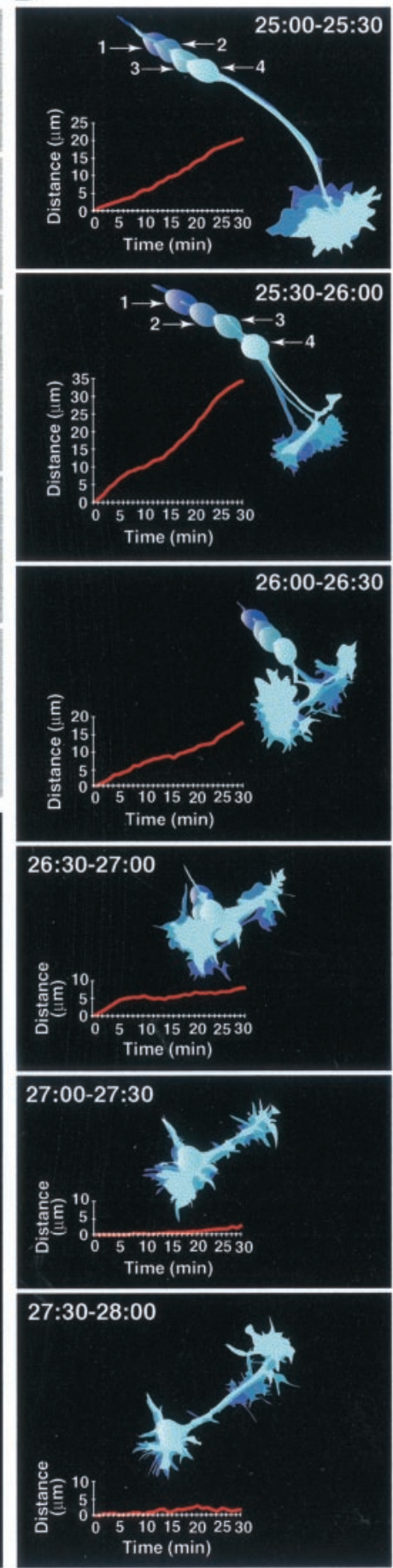
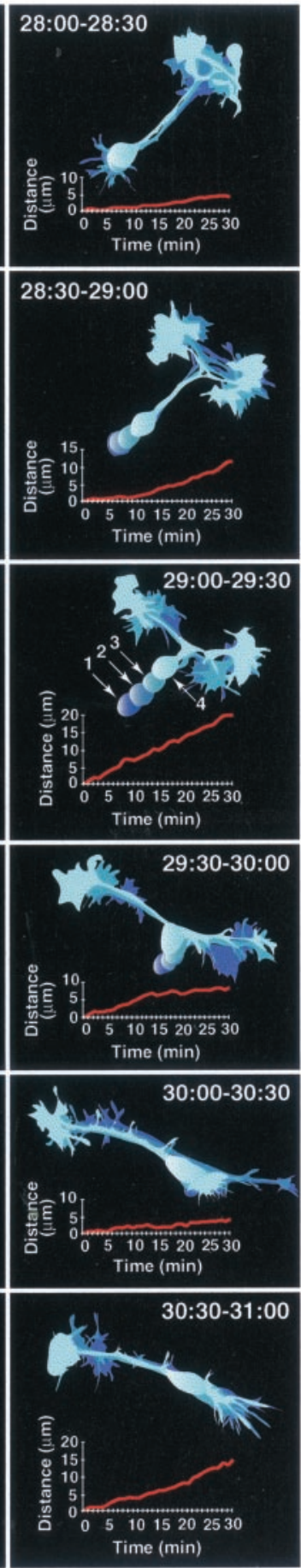

Figure 4. Bifurcation of leading process and development of right angle turn. $A$, Time lapse series of images of a migrating granule cell during the early stage of the second phase. Elapsed time in vitro is indicated on bottom of each photograph. At $25 \mathrm{hr}$ in vitro, a granule cell had a spindle-shaped soma with a thick and long leading process and a thin and short trailing process. Later, the tip of the leading process bifurcated, and then both branches extended toward opposite direction. After one of the branches collapsed and retracted, the cell body followed the direction of extension of the remaining branch. Arrows indicate the branching points of the leading process. Arrowheads indicate motile lamellipodia and filopodia at the tip of the processes. Scale bar, $18 \mu \mathrm{m}$. $B$, Changes in direction and rate of cell movement. Four images of the granule cell taken every 10 min (shown in $A$ ) are superimposed. The numbers (1-4) represent the images taken at 0,10,20, and 30 min during each 30 min recording, respectively. Elapsed time in vitro is indicated on top of each image. Each graph represents the total distance traveled by the granule cell as a function of elapsed time. $C$, Fluctuations of the rate of granule cell movement. $c 1$, Pseudocolor images represent images of the granule cell taken every 30 min shown in $A$. Each number represents the order of image taken. $c 2$, Graph showing the changes in average rate of cell movement. The color of each column corresponds to the pseudocolor of each image in $c 1$. 
A
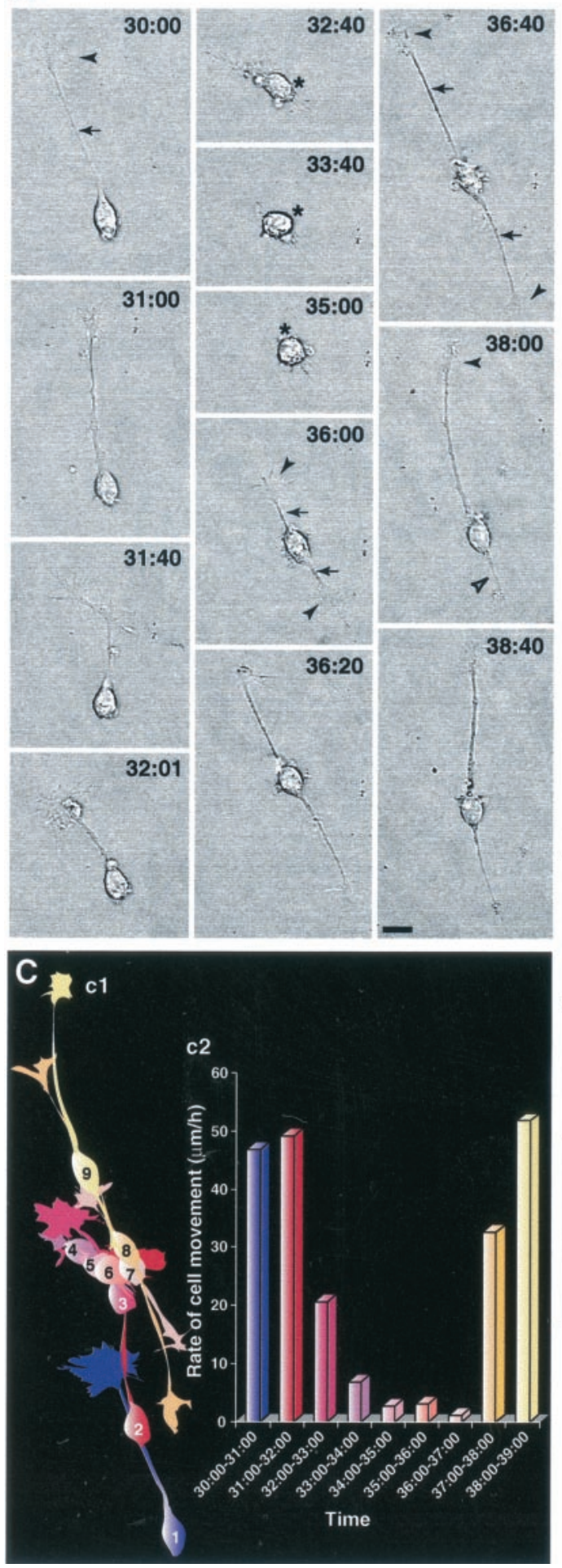

B
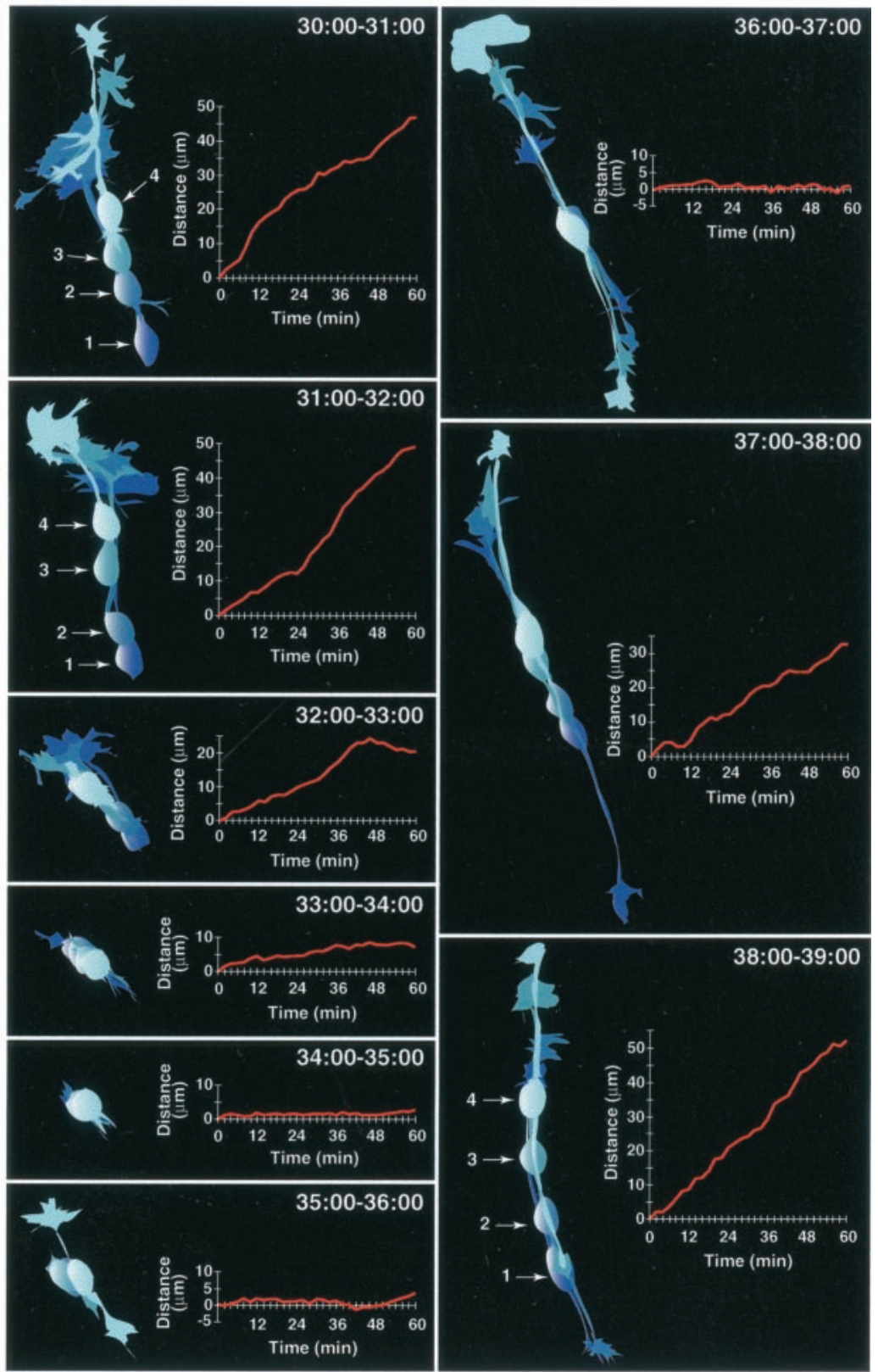

Figure 5. Retraction of leading process and prolonged stationary state. $A$, Time lapse series of images of a migrating granule cell during the late stage of the second phase. Elapsed time in vitro is indicated on top of each photograph. At $30 \mathrm{hr}$ in vitro, a granule cell had a spindle-shaped soma with a thick and long leading process and migrated at a rate of $\sim 48 \mu \mathrm{m} / \mathrm{hr}$. Thereafter, the granule cell gradually slowed down its movement, retracted the long leading process and then became stationary for $\sim 3 \mathrm{hr}$. Arrows and arrowheads indicate the leading process and motile lamellipodia at its tip, respectively. Asterisks represent the rounded cell body of the granule cell during a stationary period. Scale bar, $10 \mu \mathrm{m}$. $B$, Changes in direction and rate of cell movement. Four images of the granule cell taken every $20 \mathrm{~min}$ (shown in $A$ ) are superimposed. The numbers (1-4) represent the images taken at $0,20,40$, and 60 min during each 60 min recording, respectively. Elapsed time in vitro is indicated on top of each image. Each graph represents the total distance traveled by the granule cell as a function of elapsed time. $C$, Fluctuations of the rate of granule cell movement. $c 1$, Pseudocolor images represent images of the granule cell taken every 60 min shown in $A$. Each number represents the order of image taken. $c 2$, Graph showing the changes in average rate of cell movement. The color of each column corresponds to the pseudocolor of each image in $c 1$.

multiple branches, and then the cell body reached the base of its branches (Fig. 6A,B). As a result of collapse and retraction of the branches, at $46 \mathrm{hr}$ in vitro, the cell had two leading process-like processes that formed the L-shape and became stationary (Fig.
$6 C)$. The overall rate of cell movement was $29.9 \mu \mathrm{m} / \mathrm{hr}$ with a range between 5 and $49 \mu \mathrm{m} / \mathrm{hr}$. These results suggest that morphological changes of leading process may be an initial sign of termination of intrinsic migration of granule cells. 
A
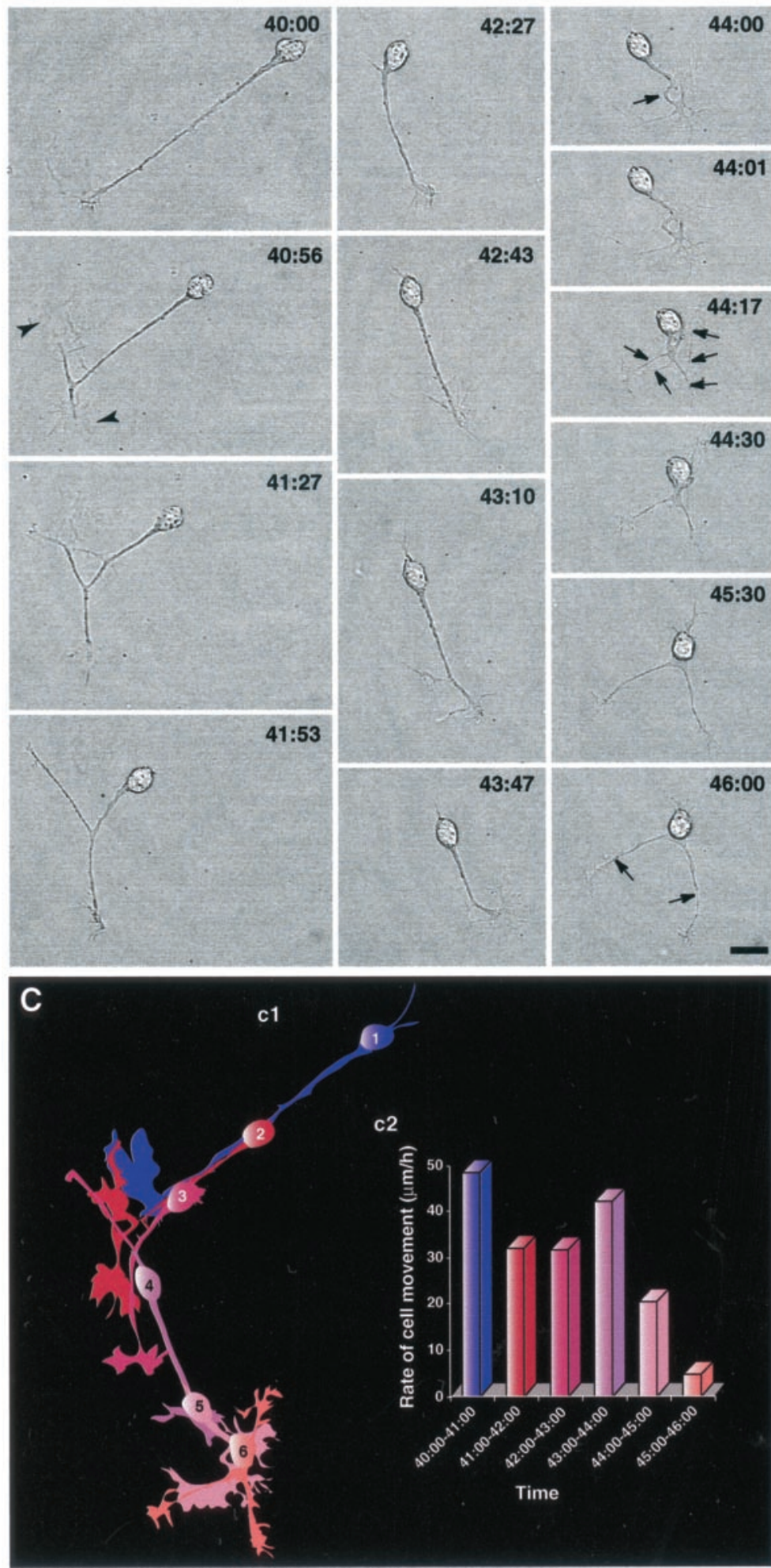

B
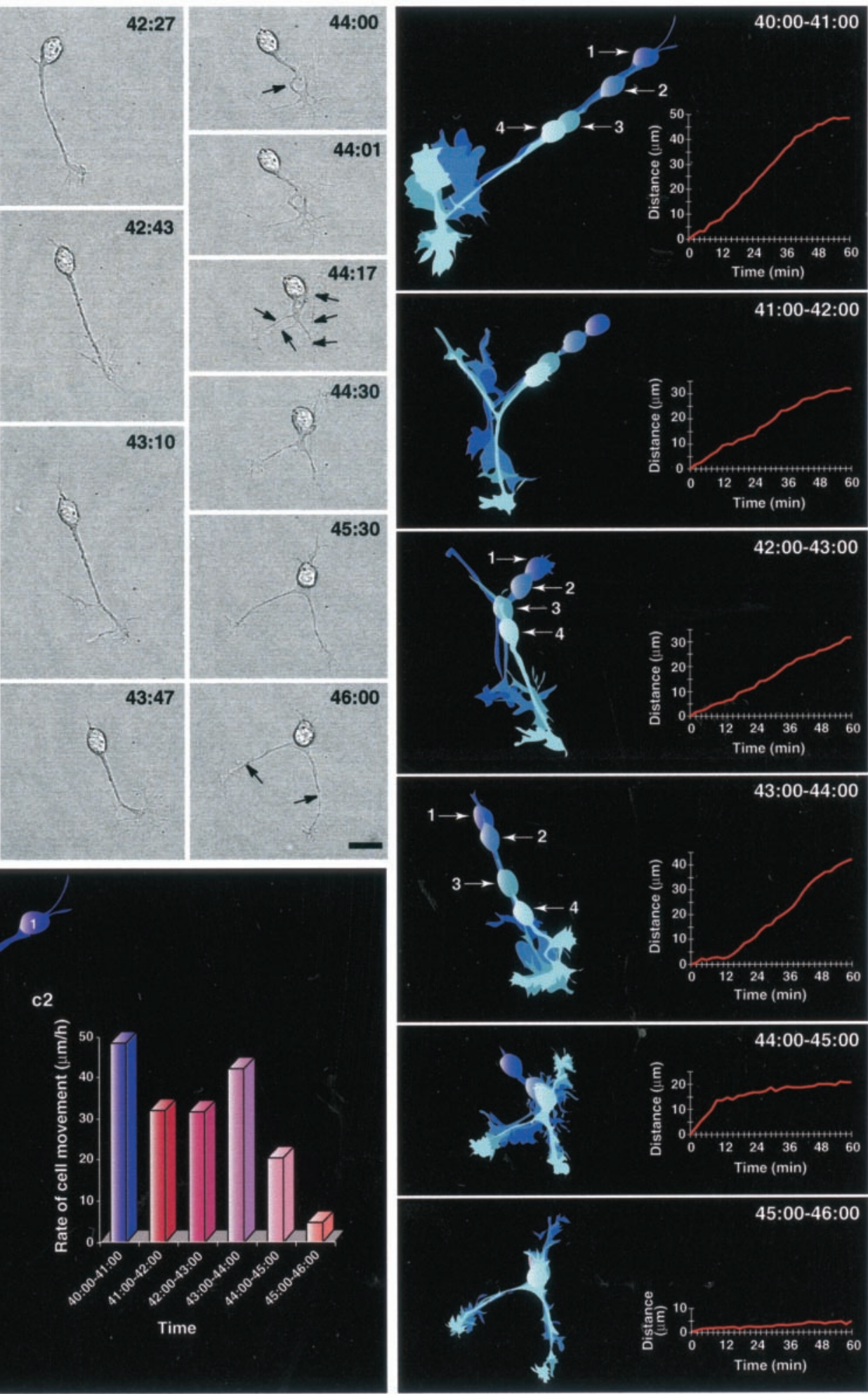

Figure 6. An initial sign of termination of granule cell migration. A, Time lapse series of images of a migrating granule cell during the early stage of the third phase. Elapsed time in vitro is indicated on top of each photograph. At $40 \mathrm{hr}$ in vitro, a granule cell had a long leading process and exhibited active cell movement. Later, the tip of the leading process started to split into multiple branches. As a result of collapsing and retraction of the branches, the granule cell had two leading process-like processes that formed the L-shape. Arrows indicate multiple leading process-like processes. Arrowheads indicate motile lamellipodia at a tip of the process. Scale bar, $13 \mu \mathrm{m} . B$, Changes in direction and rate of cell movement. Four images of the granule cell taken every $20 \mathrm{~min}$ (shown in $A$ ) are superimposed. The numbers (1-4) represent the images taken at 0, 20, 40, and 60 min during each 60 min recording, respectively. Elapsed time in vitro is indicated on top of each image. Each graph represents the total distance traveled by the granule cell as a function of elapsed time. $C$, Fluctuations of the rate of granule cell movement. $c 1$, Pseudocolor images represent images of the granule cell taken every 60 min shown in $A$. Each number represents the order of image taken. $c 2$, Graph showing the changes in average rate of cell movement. The color of each column corresponds to the pseudocolor of each image in $c 1$. 
A
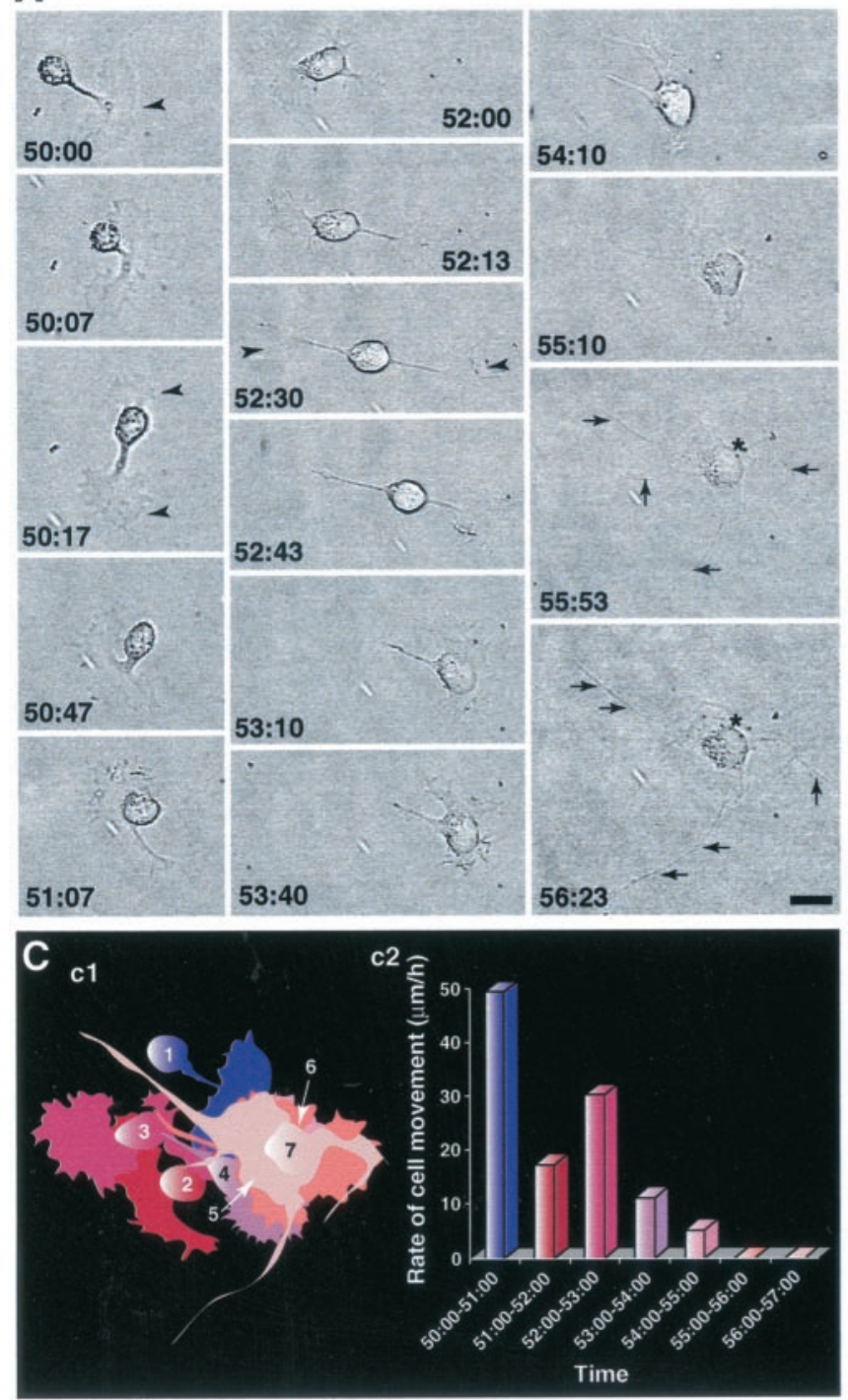

B
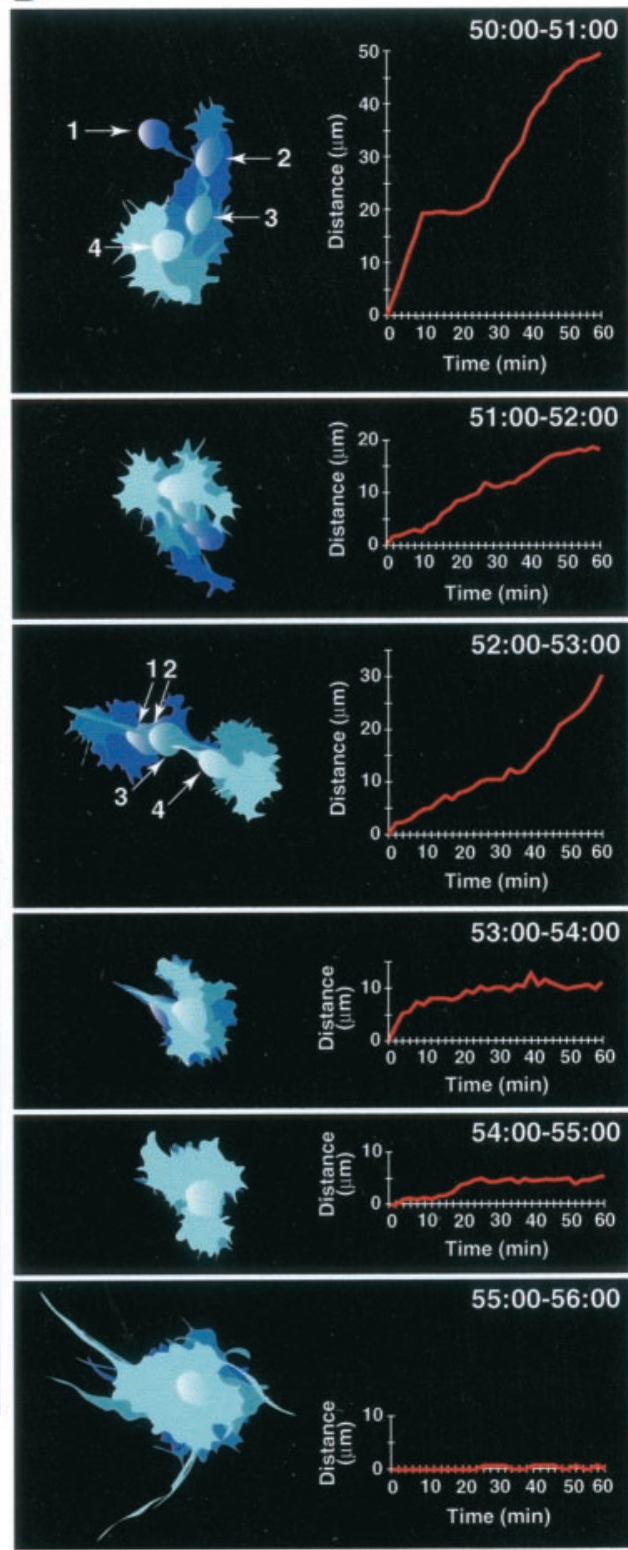

$56: 00-57: 00$

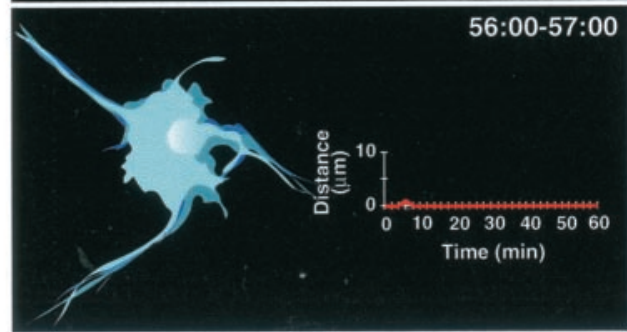

Figure 7. Completion of granule cell migration in the microexplant cultures. $A$ Time lapse series of images of a migrating granule cell during the late stage of the third phase. Elapsed time in vitro is indicated on bottom of each photograph. At 50 hr in vitro, a granule cell actively moved, repeatedly turned, and dynamically altered the morphology of the process. Thereafter, the granule cell slowed down its movement and then became permanently stationary. Arrows indicate multiple thin processes extended from the soma. Arrowheads indicate motile lamellipodia and filopodia at a tip of the process. Asterisks represent the rounded cell body of the granule cell. Scale bar, $10 \mu \mathrm{m}$. $B$, Changes in direction and rate of cell movement. Four images of the granule cell taken every $20 \mathrm{~min}$ (shown in $A$ ) are superimposed. The numbers (1-4) represent the images taken at $0,20,40$, and 60 min during each 60 min recording, respectively. Elapsed time in vitro is indicated on top of each image. Each graph represents the total distance traveled by the granule cell as a function of elapsed time. $C$, Fluctuations of the rate of granule cell movement. $c 1$,

Pseudocolor images represent images of the granule cell taken every $60 \mathrm{~min}$, shown in $A$. Each number represents the order of image taken. $c 2$, Graph showing the changes in average rate of cell movement. The color of each column corresponds to the pseudocolor of each image in $c 1$.

\section{Termination of intrinsic migration during the late stage of the third phase}

To determine how granule cells complete their migration without potential external stop signals, we further examined the final stage of granule cell migration. At $50 \mathrm{hr}$ in vitro, a granule cell had a round soma with a short voluminous process, actively moved, repeatedly turned, and dynamically altered the morphology of the process (Fig. 7A). At $52.5 \mathrm{hr}$ in vitro, the extension of the "leading process" stopped, whereas the soma of the granule cell moved toward the tip of the process. At $53 \mathrm{hr}$ in vitro, the granule cell soma arrived at the center of a fully stretched lamellipodium-like sheet of the process. At $55 \mathrm{hr}$ in vitro, the cell completely stopped its movement and extended a broad lamellipodium around the cell body (Fig. 7B). At the same time, the cell started to emit 
several thin axon-like processes radially (Fig. $7 A, B)$. The cell body became permanently stationary and did not show any sign of movement for additional several hours until the end of the experiment (Fig. $7 C$ ). In the present experiments, the majority of granule cells terminated their migration 50-60 hr after the initiation of their movement without external cues. One can argue that the termination of cell migration could be attributable to its physiological deterioration after a prolonged period of observation. However, we consider this unlikely because the cells appear healthy, and immediately after the completion of their movement start to differentiate more mature forms. Furthermore, many granule cells in the microexplant cultures, which remained in the $\mathrm{CO}_{2}$ incubator and were never imaged, also terminated their migration at these points. This $50-60 \mathrm{hr}$ term is comparable with the time required for granule cells to migrate from the EGL to the IGL in the early postnatal mouse cerebellum in vivo (Komuro and Rakic, 1998a; Komuro et al., 2001), suggesting that internal programs may be involved in the termination of granule cell migration in vivo.

\section{Alterations of intrinsic migratory behavior of granule cells by cell-cell contact}

During translocation from their birthplace to their final destination in vivo, granule cells always contact other neurons, neuronal processes, and glial processes (Rakic, 1971, Komuro and Rakic, 1998a; Komuro et al., 2001; Komuro and Yacubova, 2001). Such cell-cell interactions are involved in controlling the rate, tempo, mode, and direction of granule cell migration (Rakic, 1985a,b; Edmondson et al., 1988; Hatten and Mason, 1990, Rakic et al., 1994; Cameron and Rakic, 1994; Anton et al., 1996, 1997, 1999; Cameron et al., 1997). However, little is known about how these cell-cell interactions modify the intrinsic migratory behavior of granule cells. To address this question, we examined the mode and tempo of granule cell migration along the bundle of neurites in microexplant cultures. At $30 \mathrm{hr}$ in vitro, a granule cell had a spindle-shaped cell body that was tightly associated with a bundle of neurites (Fig. 8A). During a period between 30 and $34 \mathrm{hr}$ in vitro, the granule cell continuously migrated toward the direction of its leading process with small fluctuations of rate of cell movement in a range between 14 and $29 \mu \mathrm{m} / \mathrm{hr}$ (Fig. 8A,B). At $34.5 \mathrm{hr}$ in vitro, the soma became round, slowed down its movement (3-5 $\mu \mathrm{m} / \mathrm{hr}$ ), and paused (Fig. $8 A, B$ ). During an observation period, the granule cell neither detached from the bundle of neurites nor changed the direction of movement (Fig. 8A,C). The overall rate of movement was $15.4 \mu \mathrm{m} / \mathrm{hr}$. These results suggest that interactions between granule cells and other processes may alter the intrinsic migratory behavior of granule cells in following ways: (1) inhibition of turning, (2) reduction of speed of cell movement, and (3) leveling off fluctuation of cell movement.

\section{Sequential alterations of granule cell migratory behavior and its morphology without cell-cell contact}

To further elucidate intrinsic programs for cell migration, we examined the relationship between the migratory behavior of isolated granule cells, their morphology, and the elapsed time after an initiation of cultures. As presented quantitatively in the histograms (Fig. 9a-g), the morphology and behavior of isolated granule cells in the microexplant cultures depends on the elapsed time (or developmental stage), and the majority of isolated granule cells underwent sequential transformations. For example, in the first phase $(0-20 \mathrm{hr}$ in vitro), granule cells migrate at an average rate of $26.0 \pm 2.4 \mu \mathrm{m} / \mathrm{hr}$ and exhibit the highest rate of turning behavior $(1.3 \pm 0.2$ turns per hr), when the cells have multiple $(3.7 \pm 0.1$ processes per cell $)$ and short $(20.8 \pm 2.1 \mu \mathrm{m})$ processes. The length of cycle of cell movement and stationary state is shortest $(218 \pm 16 \mathrm{~min})$. In the second phase $(20-40 \mathrm{hr}$ in vitro), granule cells extend a long and thick leading process-like process $(55.6 \pm 3.0 \mu \mathrm{m})$ and exhibit an elongated cycle $(244 \pm 13$ min) of cell movement and stationary state. The rate of cell movement is fastest $(33.1 \pm 2.0 \mu \mathrm{m} / \mathrm{hr})$, whereas the number of turning is lowest $(0.3 \pm 0.1$ turns per hr). In the third phase (40-60 hr in vitro), granule cells slow down their movement $(25.2 \pm 3.2 \mu \mathrm{m} / \mathrm{hr})$, but slightly increase the turning number $(0.5 \pm 0.1$ turns per $\mathrm{hr})$. The length of cycle of cell movement further increases to $297 \pm 21 \mathrm{~min}$. These results demonstrate that granule cells sequentially alter mode, rate, and direction of migration and morphology in vitro without contacting other neurons or glial cells.

\section{Existence of intrinsic programs for controlling migratory behavior of granule cells}

If there is a strong intrinsic program for controlling migratory behavior, isolated granule cells may exhibit similar characteristic phases of migration in different adhesive substrates and in different concentrations of laminin. Furthermore, granule cells isolated from different postnatal stages also may undergo the same patterns of changes in migratory behavior. To address these issues, we determined migratory behavior of isolated granule cells in a fibronectin $(20 \mu \mathrm{g} / \mathrm{ml})$ and in a lower $(4 \mu \mathrm{g} / \mathrm{ml})$ or higher $(100$ $\mu \mathrm{g} / \mathrm{ml})$ concentration of laminin. Moreover, we observed sequential changes of granule cell migration in the microexplant cultures prepared from postnatal 5-d-old mouse cerebella. The results are presented quantitatively in Figure $10 a-g$. Although there were some differences in the rates of cell behavior among the four different experimental groups, the majority of isolated granule cells displayed the same patterns of behavioral and morphological changes during characteristic three phases in isolation as follows: (1) the rate of cell movement in the second phase was fastest (Fig. $10 a),(2)$ the rate of turning behavior in the first phase was highest (Fig. 10b), (3) the length of cycle of cell movement systematically increased as time in vitro increased (Fig. 10c), (4) the length of the stationary state in the second phase was longest (Fig. 10d), (5) the number of processes was largest in the first phase (Fig. 10f), and (6) the length of process in the third phase was longest (Fig. 10g). These results demonstrate the existence of intrinsic (inherent) programs for controlling migratory behavior of granule cells in an age-dependent manner (or a developmental stage-dependent manner). These results suggest that such internal programs may play a crucial role in distinct modes of granule cell migration in different cortical layers of the developing cerebellum in vivo.

\section{DISCUSSION}

In the present study, we determined whether and how intrinsic programs control migratory behavior and morphology of immature neurons in the absence of cell-cell interactions. The real time observation of cell movement reveals that granule cells intrinsically and sequentially go through three characteristic phases of behavior and morphology without contacting other cells and processes in microexplant cultures of early postnatal mouse cerebella, indicating that inherent (intrinsic) mechanisms control alterations of morphology and migratory behavior.

How do these patterns of intrinsic migration without cell-cell contact in vitro compare with those observed in vivo? How significantly is the granule cell migration modified by cell-cell contact? 
A

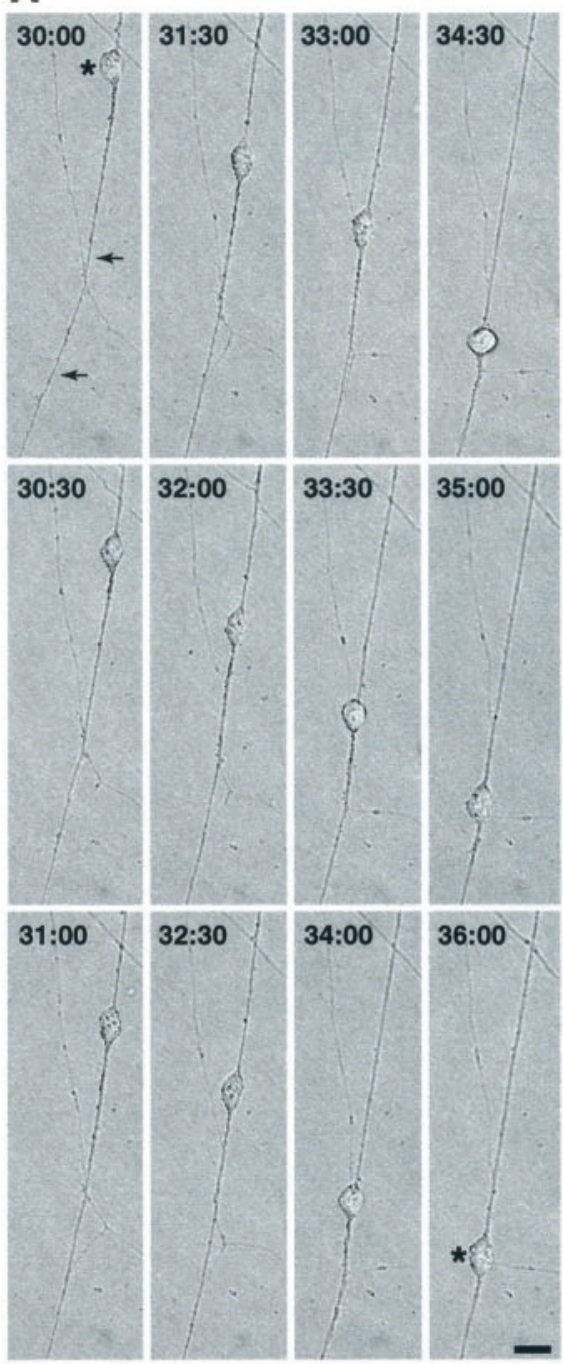

Figure 8. Granule cell migration along bundle of neuronal processes in the microexplant cultures. $A$, Time lapse series of images of a migrating granule cell during the second phase. Elapsed time in vitro is indicated on top of each photograph. At $30 \mathrm{hr}$ in vitro, a granule cell had a spindle-shaped cell body that was tightly associated with a bundle of neurites. During a period of observation, the granule cell soma neither detached from the bundle of neurites nor changed the direction of movement. Arrows indicate bundle of neurites, and asterisks indicate the granule cell soma. Scale bar, $10 \mu \mathrm{m}$. $B$, Changes in direction and rate of cell movement. Four images of the granule cell taken every $10 \mathrm{~min}$ (shown in $A$ ) are superimposed. The numbers (1-4) represent the images taken at $0,10,20$, and 30 min during each $30 \mathrm{~min}$ recording, respectively. Elapsed time in vitro is indicated on top of each image. Each graph represents the total distance traveled by the granule cell as a function of elapsed time. $C$, Fluctuations of the rate of granule cell movement. $c 1$, Pseudocolor images represent images of the granule cell taken every 30 min shown in $A$. Each number represents the order of image taken. $c 2$, Graph showing the changes in average rate of cell movement. The color of each column corresponds to the pseudocolor of each image in $c 1$.

As schematically represented in Figure $11 A$, granule cells exhibit a distinct migratory behavior and their morphology in the different cortical layers of the early postnatal cerebellum (Komuro and Rakic, 1995, 1998a; Komuro et al., 2001; Yacubova and Komuro, 2002). Present results demonstrate that in the microexplant cultures isolated granule cells sequentially go through three characteristic phases of migration without cell-cell contact (Fig. 11B). The comparison between migration in vivo and in vitro suggests
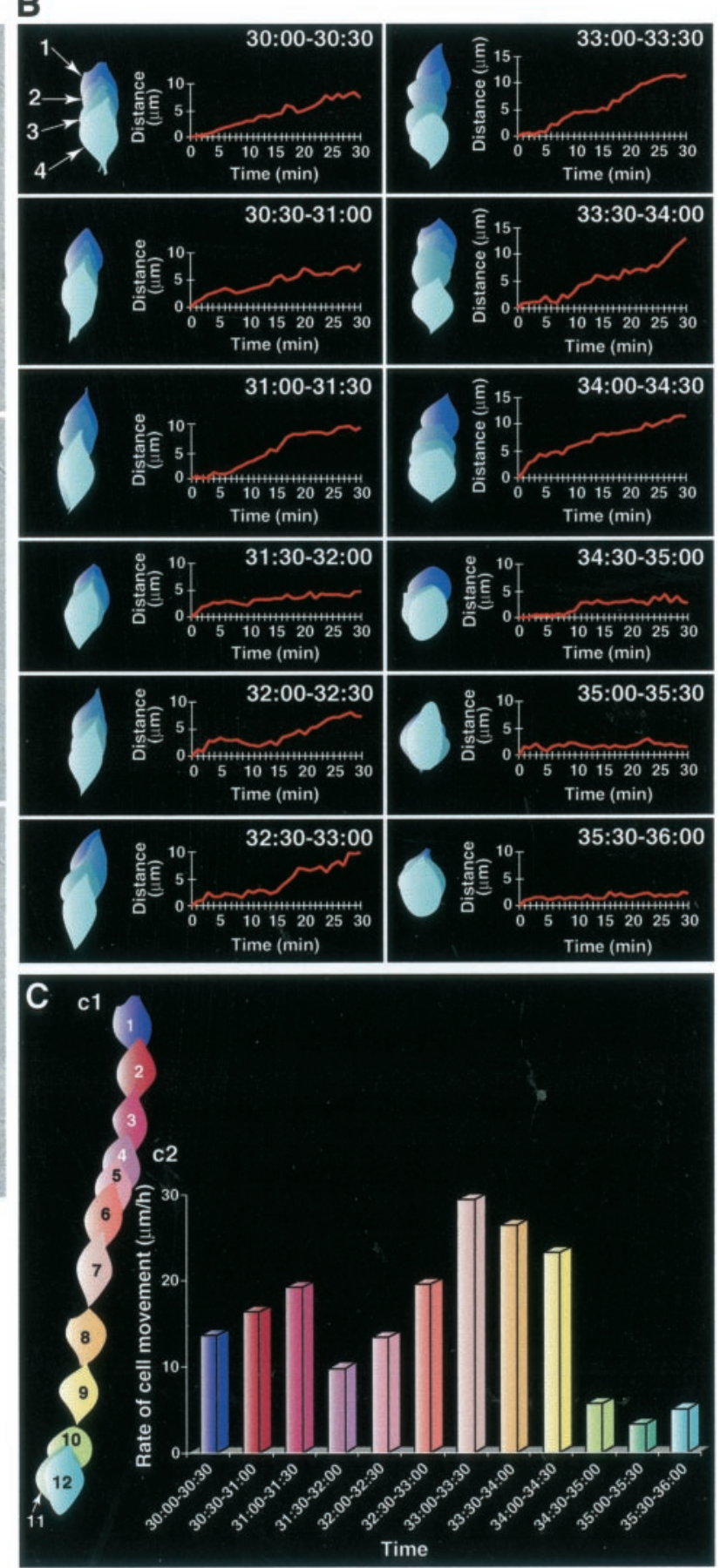


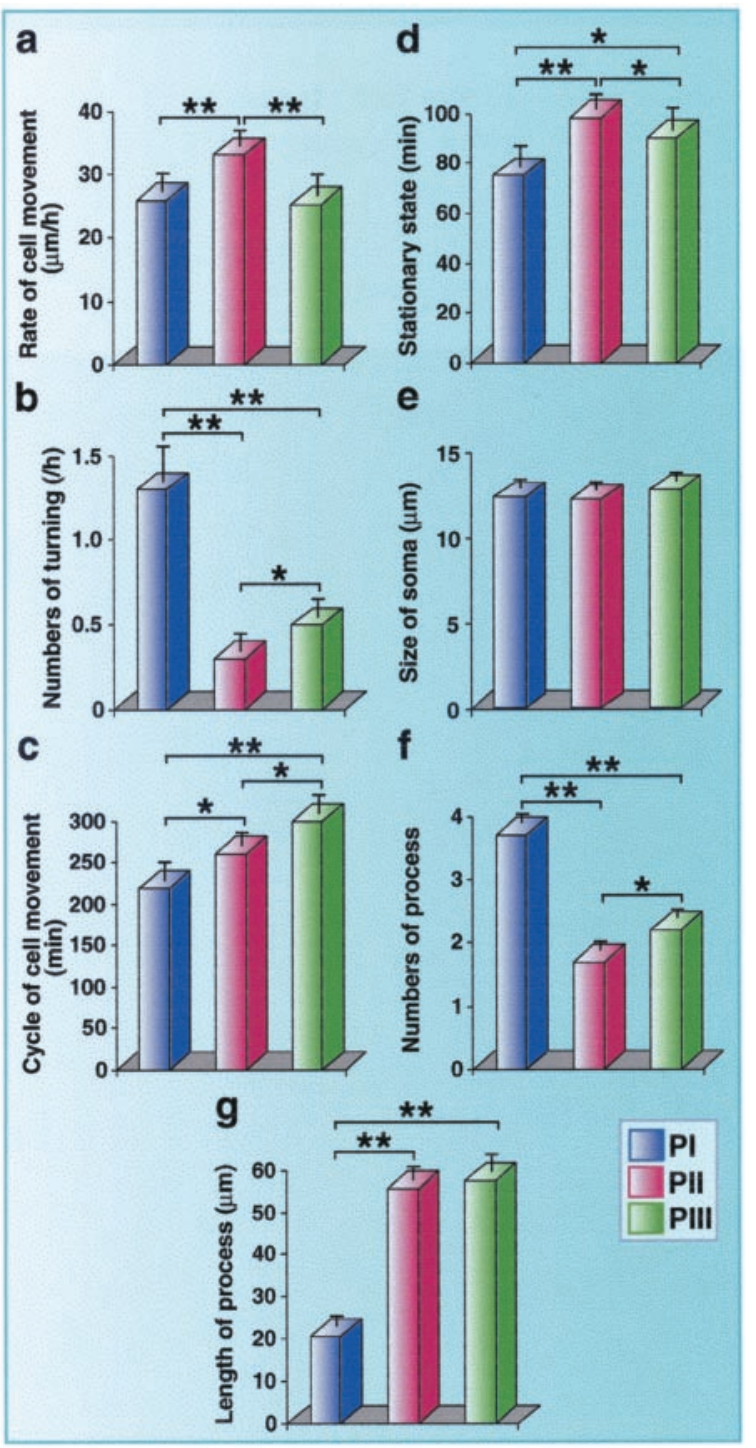

Figure 9. Sequential changes in morphology and migratory behavior of granule cells in PI, PII, and PIII. $a-g$, Histograms of rate of cell movement $(a)$, numbers of turning $(b)$, cycle of cell movement $(c)$, stationary state $(d)$, size of soma $(e)$, numbers of process $(f)$, and length of process $(g)$ of granule cells in PI, PII, and PIII. Each column represents the average values obtained from $>30$ migrating granule cells. ${ }^{*} p<0.05$ and ${ }^{* *} p<$ 0.01 indicate statistical significance. Error bars indicate SD.

two long processes and move at the fastest rate, whereas in the ML in vivo (20-30 hr after the initiation of migration) granule cells have a long leading process and a trailing process and move radially at an increased rate. The similarity suggests that the alteration of granule cell migration observed in the ML may be regulated, at least in part, by intrinsic programs. Furthermore, in PIII (40-60 hr in vitro) granule cells terminate their migration without cell-cell contact and start to express $\alpha 6$ subunit of $\mathrm{GABA}_{\mathrm{A}}$ receptors, which are expressed only when the cells arrive in the IGL in vivo (Mellor et al., 1998; Yacubova and Komuro, 2002), suggesting that granule cells in PIII may be in a similar stage of differentiation with those in the IGL. The time schedule for completion of migration in vitro is quite similar to that for granule cell migration in vivo: it takes $\sim 51 \mathrm{hr}$ for the cells to translocate from their birthplace to their final destination in vivo (Komuro and Rakic, 1998a; Komuro et al., 2001). This similarity indicates that an internal program (or clock) may be involved in determining the term of cell migration, as originally suggested by previous studies (Trenkner et al., 1984).

Granule cells exhibit distinct rates of cell movement while they migrate in different cortical layers in vivo (Komuro and Rakic, 1995, 1998a; Komuro et al., 2001). Although these alterations of rate in vivo are likely attributable to different modes of migration (glia-associated or glia-independent) and to differences in microenvironments (Rakic, 1990; Hatten and Mason, 1990; Rakic et al., 1994), sequential changes in the rate without cell-cell contact in vitro (schematically represented in Fig. 11C) suggests that granule cells may intrinsically change their speed in vivo. The mechanisms underlying sequential changes in the rate of granule cell migration in vitro and in vivo remain to be examined, but there is a possible scenario. In this study, granule cells migrate on laminin, which promotes frequent and rapid migration among extracellular matrix molecules (Liesi, 1990; Fishell and Hatten, 1991; Fishman and Hatten, 1993). Importantly, the speed of cell movement depends on several variables related to receptor-ligand interactions, including ligand levels (such as laminin), receptor levels (such as integrin), and receptor-ligand binding affinities (Palecek et al., 1997). For example, the laminin concentration promoting maximum migration speed decreases reciprocally as integrin expression increases. On the other hand, increases in integrinligand affinity similarly result in maximum migration at reciprocally lower ligand concentrations (Palecek et al., 1997). Therefore, if granule cells alter the levels of receptors for extracellular matrix and cell adhesion molecules, the rate of cell movement may change although their microenvironments are the same. Interestingly, granule cells sequentially express different complements of genes that encode for receptors for extracellular matrix and cell adhesion molecules along their migratory pathway in vivo (Kuhar et al., 1993; Hatten and Heintz, 1995). These lines of evidence, as a whole, suggest that changes in speed of granule cell migration in vitro as well as in vivo may be explained, at least in part, by alteration in levels of receptors for extracellular matrix and cell adhesion molecules. However, exact levels of these receptors in vitro and in vivo remain to be determined.

The present results demonstrate that granule cells sequentially develop four different modes of turning as the differentiation goes on. First, undifferentiated granule cells, which do not have a leading process, alter the direction of movement by reorientation of the longitudinal axis of their somata (Fig. 11d1). Second, granule cells withdraw their process and then extend a new process toward the direction of upcoming movement (Fig. 11d2). Third, the turning of the tip of the process to a new direction is followed by their somata (Fig. 11d3). Fourth, the leading process bifurcates, and the nucleus and surrounding cytoplasm enter into one of the branches (Fig. 11d4). Although the significance of changes in turning behavior of isolated granule cells remains to be determined, there are hints to understand how alteration of turning mode plays a critical role in an execution of granule cell migration in vivo. In the developing cerebellum, postmitotic granule cells change the direction of cell movement only once during an entire course of migration from their birthplace to their final destination (Komuro et al., 2001; Komuro and Yacubova. 2001). At the interface of the EGL and the ML ( 20-30 hr after the initiation of migration), tangentially migrating granule cells start to extend a vertical process and initiate the transition from tangential to radial migration (Komuro et al., 2001). Interestingly, in the microexplant cultures, at $20-30 \mathrm{hr}$ in vitro granule cells developed fourth mode of turning (Fig. 11d4), which is charac- 


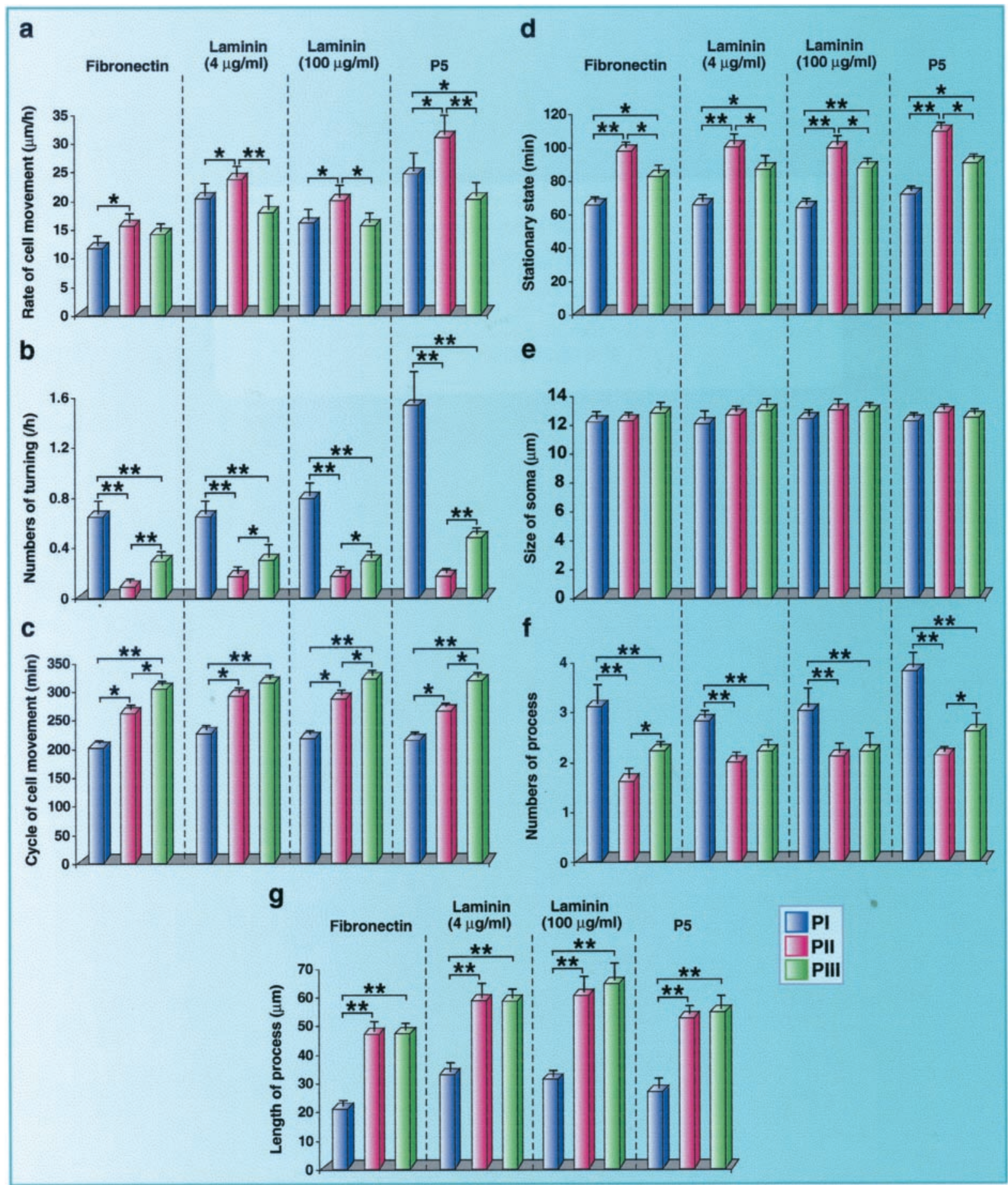

Figure 10. Existence of intrinsic programs for controlling migratory behavior of granule cells. $a-g$, Histograms of rate of cell movement $(a)$, numbers of turning $(b)$, cycle of cell movement $(c)$, stationary state $(d)$, size of soma $(e)$, numbers of process $(f)$, and length of process $(g)$ of granule cells in PI, PII, and PIII. Sequential changes in migratory behavior of granule cells prepared from postnatal 0- to 2-d-old mouse cerebella were determined in a fibronectin $(20 \mu \mathrm{g} / \mathrm{ml})$ and in a lower $(4 \mu \mathrm{g} / \mathrm{ml})$ or higher $(100 \mu \mathrm{g} / \mathrm{ml})$ concentration of laminin. In addition, we observed alterations of granule cell migration in the microexplant cultures of postnatal 5-d-old mouse cerebella. Each column represents the average values obtained from $>15$ migrating granule cells. ${ }^{*} p<0.05$ and ${ }^{*} p<0.01$ indicate statistical significance. Error bars indicate SD.

terized by bifurcation of leading process and extension of the branches at a right angle. The development of this mode of turning at 20-30 hr after the initiation of migration may be essential for the alteration of direction of granule cell movement in the EGL-ML border in vivo. However, to determine whether and how sequential changes in turning behavior observed in vitro play crucial roles in granule cell migration in vivo, studies such as transplantation of isolated granule cells into cerebellum at different stages of development and monitoring their behavior in vivo are needed. The use of knock-out mice and mutant mice may also facilitate the understanding of developmental role of each mode of turning behavior. 


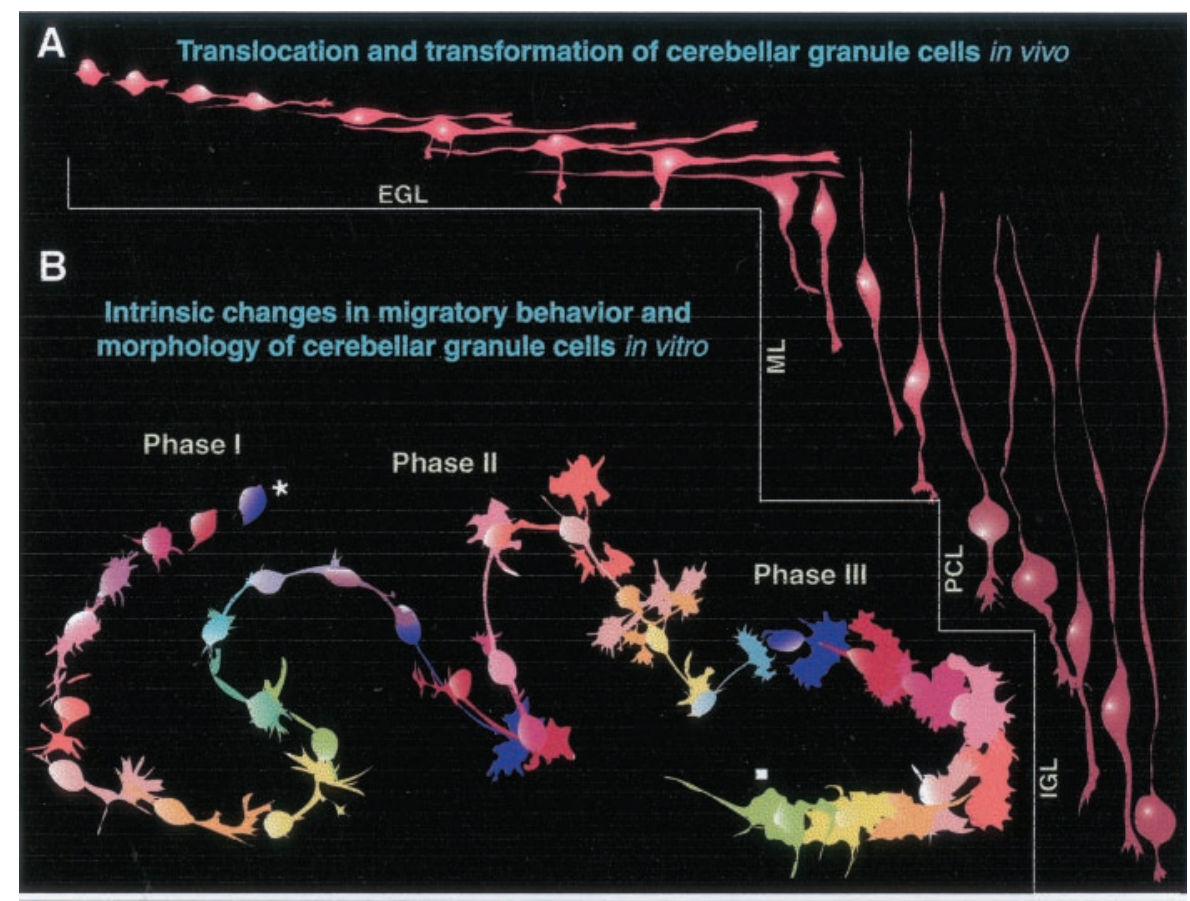

Figure 11. Schematic representation of autonomous changes in morphology and behavior of granule cells in vivo and in vitro. $A$, Migration of granule cells in the early postnatal cerebellum. $B$, Transformation of granule cells in PI, PII, and PIII. A white asterisk indicates a granule cell in the early stage of the first phase, and a white square indicates a postmigratory granule cell in the late stage of the third phase. $C$, Alterations of speed and length of cycle of cell movement in PI, PII, and PIII. $D$, Sequential development of four different modes of turning. $d 1$, Undifferentiated granule cells, which do not have a leading process, alter the direction of movement by reorientation of the longitudinal axis of their somata (mode 1$). d 2$, Granule cells withdraw their process and then extend a new process toward the direction of upcoming movement (mode 2). $d 3$, Turning of the tip of the leading process to a new direction is followed by their somata (mode 3 ). $d 4$, Leading process bifurcates, and the nucleus and surrounding cytoplasm enter into one of the branches (mode 4). Arrows indicate the direction of cell movement.
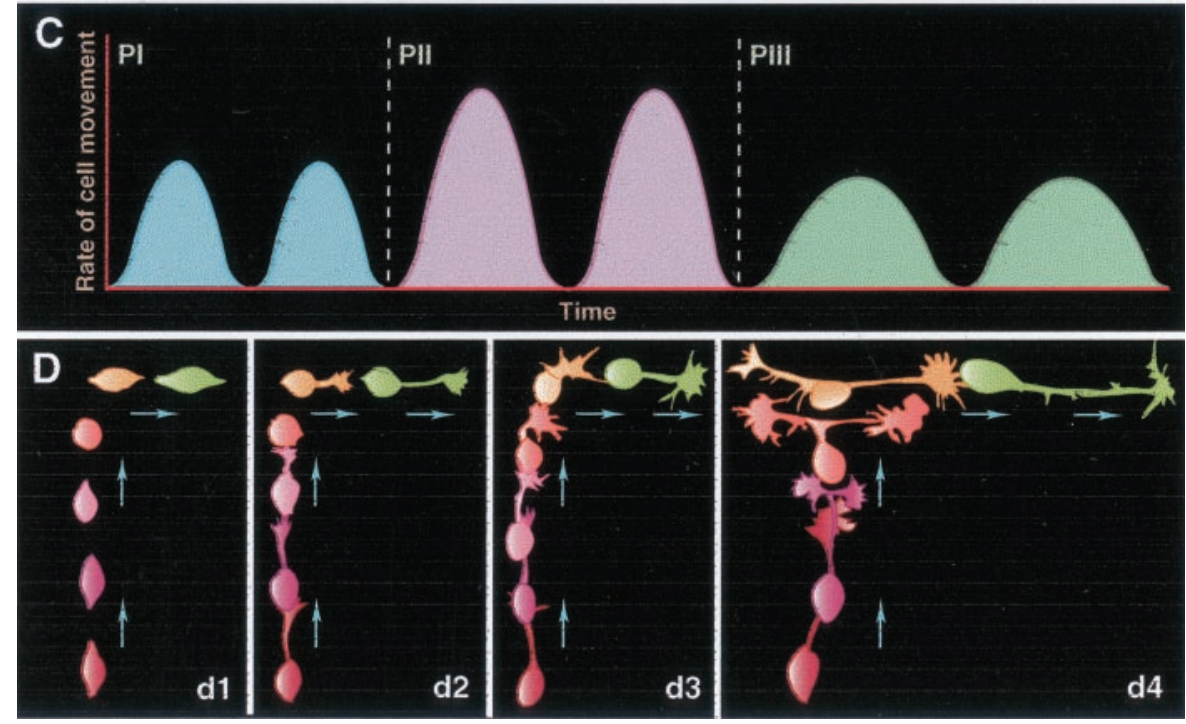

Autonomous changes in migratory behavior of granule cells may be controlled by sequential expression of multiple genes, transcription factors, voltage-dependent ion channels, and small G-proteins (Hatten and Heintz, 1995; Hatten et al., 1997; Komuro and Rakic, 1998b; Hatten, 1999). Among putative signals that control migratory behavior, transient elevations of intracellular $\mathrm{Ca}^{2+}$ levels may be one of many key players. Interestingly, granule cells exhibit distinct patterns of $\mathrm{Ca}^{2+}$ fluctuations in different migratory phases (Yacubova and Komuro, 2002; our unpublished results). In PI, $\mathrm{Ca}^{2+}$ levels of granule cell somata irregularly elevate with small peaks. In PII, granule cells start to exhibit spike-like $\mathrm{Ca}^{2+}$ elevations, although the number of the spike is low and the majority of $\mathrm{Ca}^{2+}$ fluctuations are small and irregular. In PIII, the number of $\mathrm{Ca}^{2+}$ spike significantly increases. These changes could be important, because alterations of intracellular $\mathrm{Ca}^{2+}$ levels influence the speed of granule cell movement (Komuro and Rakic, 1992, 1993, 1996; Yacubova and
Komuro, 2002). It has been shown that spikes and waves of $\mathrm{Ca}^{2+}$ transients encode information in their frequency and implement an intrinsic development program in spinal neurons $(\mathrm{Gu}$ and Spitzer, 1995; Spitzer and Gu, 1997). Therefore, development of $\mathrm{Ca}^{2+}$ transients may be essential for autonomous changes in granule cell migration. Moreover, sequential expression of cytoskeletal components may also be involved in inherent changes in behavior and morphology, because granule cells are highly polarized in the direction of migration, and spatial and temporal changes in the cytoskeleton are required for alteration of orientation and cell movement (Gregory et al., 1988; Lin et al., 1994; Ono et al., 1994; Rivas and Hatten, 1995). The leading processes and trailing processes of granule cells exhibit a distinct orientation of cytoskeletal components (Rakic et al., 1996) and express cytoskeletal components in the following order: (1) actincontaining microfilaments, (2) microtubules, and (3) neurofilaments (Cambray-Deakin et al., 1987). These lines of evidence 
suggest that genetically programmed order of expression of cytoskeletal components may be crucial for alterations of migratory behavior of granule cells and their morphology.

\section{REFERENCES}

Alcantara S, Ruiz M, De Castro F, Soriano E, Solelo C (2000) Netrin 1 acts as an attractive or as a repulsive cue for distinct migrating neurons during the development of the cerebellar system. Development 127:1359-1372.

Altman J (1972) Postnatal development of the cerebellar cortex in the rat. I. The external germinal layer and the transitional molecular layer. J Comp Neurol 145:353-398.

Anton E, Cameron RS, Rakic P (1996) Role of neuron-glial junctional domain proteins in the maintenance and termination of neuronal migration across the embryonic cerebral wall. J Neurosci 16:2283-2293.

Anton E, Marchionni MA, Lee K-F, Rakic P (1997) Role of GGF/ neuregulin signaling in interactions between migrating neurons and radial glia in the developing cerebral cortex. Development 124:3501-3510.

Anton E, Kreidberg JA, Rakic P (1999) Distinct function of $\alpha_{3}$ and $\alpha_{\mathrm{V}}$ integrin receptors in neuronal migration and laminar organization of the cerebral cortex. Neuron 22:277-289.

Cambray-Deakin MA, Morgan A, Burgoyne RD (1987) Sequential appearance of cytoskeletal components during the early stages of neurite outgrowth from cerebellar granule cell in vitro. Dev Brain Res 37:197-207.

Cameron RS, Rakic P (1994) Identification of membrane proteins that comprise the plasmalemmal junction between migrating neurons and radial glial cells. J Neurosci 14:3139-3155.

Cameron RS, Ruffin J, Cho NK, Cameron PL, Rakic P (1997) Developmental expression, pattern of distribution, and effect on cell aggregation implicate a neuron-glial junctional domain protein in neuronal migration. J Comp Neurol 387:467-488.

Edmondson JC, Hatten ME (1987) Glial-guided granule neuron migration in vitro: a high-resolution time-laps video microscopic study. J Neurosci 7:1928-1934.

Edmondson JC, Liem RK, Kuster JE, Hatten ME (1988) Astrotactin, a novel cell surface antigen that mediates neuron-glia interactions in cerebellar microcultures. J Cell Biol 106:505-517.

Fishell G, Hatten ME (1991) Astrotactin provides a receptor system for CNS neuronal migration. Development 113:755-765.

Fishman RB, Hatten ME (1993) Multiple receptor systems promote CNS neuronal migration. J Neurosci 13:3485-3495.

Fujita S, Shimada M, Nakamura T (1966) $\mathrm{H}^{3}$-thymidine autoradiographic studies on the cell proliferation and differentiation in the external and the internal granular layers of the mouse cerebellum. J Comp Neurol 128:191-208.

Gregory WA, Edmondson JC, Hatten ME, Mason CA (1988) Cytology and neuron-glial apposition of migrating cerebellar granule cells in vitro. J Neurosci 8:1728-1738.

Gu X, Spitzer NC (1995) Distinct aspects of neuronal differentiation encoded by frequency of spontaneous $\mathrm{Ca}^{2+}$ transients. Nature $375: 784-787$

Hatten ME (1999) Central nervous system neuronal migration. Annu Rev Neurosci 22:511-539.

Hatten ME, Heintz N (1995) Mechanisms of neural patterning and specification in the developing cerebellum. Annu Rev Neurosci 18:385-408.

Hatten ME, Mason CA (1990) Mechanisms of glial-guided neuronal migration in vitro and in vivo. Experientia 46:907-916.

Hatten ME, Alder J, Zimmerman K, Heinntz N (1997) Genes involved in cerebellar cell specification and differentiation. Curr Opin Neurobiol 7:40-47.

Komuro H, Rakic P (1992) Selective role of N-type calcium channels in neuronal migration. Science 257:806-809.

Komuro H, Rakic P (1993) Modulation of neuronal migration by NMDA receptors. Science 260:95-97.

Komuro H, Rakic P (1995) Dynamics of granule cell migration: A confocal microscopic study in acute cerebellar slice preparations. J Neurosci 15:1110-1120.

Komuro H, Rakic P (1996) Intracellular $\mathrm{Ca}^{2+}$ fluctuations modulate the rate of neuronal migration. Neuron 17:275-285.

Komuro H, Rakic P (1998a) Distinct modes of neuronal migration in different domains of developing cerebellar cortex. J Neurosci 18:1478-1490.

Komuro H, Rakic P (1998b) Orchestration of neuronal migration by activity of ion channels, neurotransmitter receptors, and intracellular $\mathrm{Ca}^{2+}$ fluctuations. J Neurobiol 37:110-130.

Komuro H, Rakic P (1999) In vitro analysis of signal mechanisms in- volved in neuronal migration. In: The neuron in tissue culture (Haynes LW, ed), pp 57-69. New York: Wiley.

Komuro H, Yacubova E (2001) Migration of cerebellar granule cell. Cell Technol 20:513-519.

Komuro H, Yacubova E, Yacubova E, Rakic P (2001) Mode and tempo of tangential cell migration in the cerebellar external granular layer. J Neurosci 21:527-540.

Kuhar SG, Feng L, Vidan S, Ross ME, Hatten ME, Heintz N (1993) Changing patterns of gene expression define four stages of cerebellar granule neuron differentiation. Development 117:97-104.

Liang S, Crutcher KA (1992) Neuronal migration on laminin in vitro. Dev Brain Res 66:127-132.

Liang S, Crutcher KA (1993) Movement of embryonic chick sympathetic neurons on laminin in vitro is preceded by neurite extension. J Neurosci Res 36:607-620.

Liesi P (1985) Do neurons in the vertebrate CNS migrate on laminin? EMBO J 4:1163-1170.

Liesi P (1990) Extracellular matrix and neuronal movement. Experientia 46:900-907.

Liesi P (1992) Neuronal migration on laminin involves neuronal contact formation followed by nuclear movement inside a preformed process.

Lin C-H, Thompson CA, Forscher P (1994) Cytoskeletal reorganization underlying growth cone motility. Curr Opin Neurobiol 4:640-647.

Lin JC, Cepko CL (1998) Granule cell raphes and parasagittal domains of Purkinje cells: Complementary patterns in the developing chick cerebellum. J Neurosci 18:9342-9353.

Mellor JR, Merlo D, Jones A, Wisden W, Randall AD (1998) Mouse cerebellar granule cell differentiation: electrical activity regulates the $\mathrm{GABA}_{\mathrm{A}}$ receptor $\alpha 6$ subunit gene. J Neurosci 18:2822-2833.

Miale IL, Sidman RL (1961) An autoradiographic analysis of histogenesis in the mouse cerebellum. Exp Neurol 4:277-296.

Morest DK (1970) A study of neurogenesis in the forebrain of opossum pouch young. Z Anat Entwicklungsgesch 130:265-305.

Nagata I, Nakatsuji N (1990) Granule cell behavior on laminin in cerebellar microexplant cultures. Dev Brain Res 52:63-73.

Nakatsuji N, Nagata I (1989) Paradoxical perpendicular contact guidance displayed by mouse cerebellar granule cell neurons in vitro. Development 106:441-447.

Ono K, Nakatsuji N, Nagata I (1994) Migration behavior of granule cell neurons in cerebellar cultures. II An electron microscopic study. Dev Growth Differ 36:29-38.

Palecek SP, Loftus JC, Ginsberg MH, Lauffenbuger DA, Horwitz AF (1997) Integrin-ligand binding properties govern cell migration speed through cell-substratum adhesiveness. Nature 385:537-540.

Powell SK, Rivas R, Rodriguez-Boulan E, Hatten ME (1997) Development of polarity in cerebellar granule neurons. J Neurobiol 32:223-236.

Rakic P (1971) Neuron-glia relationship during granule cell migration in developing cerebellar cortex. A golgi and electron microscopic study in Macacus rhesus. J Comp Neurol 141:283-312.

Rakic P (1985a) Mechanisms of neuronal migration in developing cerebellar cortex. In: Molecular basis of neural development (Edelman GE, Cowan WM, and Gall E, eds), pp 139-160. New York: Wiley.

Rakic P (1985b) Contact regulation of neuronal migration. In: The cell in contact: adhesions and junctions as morphogenetic determinants (Edelman GM, Thiery J-P, eds), pp 67-91. New York: Wiley.

Rakic P (1990) Principles of neuronal cell migration. Experientia 46:882-891.

Rakic P, Komuro H (1995) The role of receptor/channel activity in neuronal cell migration. J Neurobiol 26:299-315.

Rakic P, Cameron RS, Komuro H (1994) Recognition, adhesion, transmembrane signaling and cell motility in guided neuronal migration. Curr Opin Neurobiol 4:63-69.

Rakic P, Knyihar-Csillik E, Csillik B (1996) Polarity of microtubule assembly during neuronal migration. Proc Natl Acad Sci USA 93:9218-9222.

Rivas RJ, Hatten ME (1995) Motility and cytoskeletal organization of migrating cerebellar granule neurons. J Neurosci 15:981-989.

Soriano E, Alvarado-Mallart RM, Dumesnil N, Del Rio JA, Sotelo C (1997) Cajal-Retzius cells regulate the radial glia phenotype in the adult and developing cerebellum and alter granule cell migration. Neuron 18:563-577.

Spitzer NC, Gu X (1997) Purposeful patterns of spontaneous calcium transients in embryonic spinal neurons. Semin Cell Dev Biol 8:13-19.

Trenkner E, Sidman RL (1977) Histogenesis of mouse cerebellum in microwell cultures. J Cell Biol 75:915-940.

Trenkner E, Smith D, Segil N (1984) Is cerebellar granule cell migration regulated by an internal clock? J Neurosci 4:2850-2855.

Yacubova E, Komuro H (2002) Stage specific control of neuronal migration by somatostatin. Nature 415:77-81. 